\title{
DOES THE "NEW ECONOMY" MEASURE UP TO THE GREAT INVENTIONS OF THE PAST?
}

\author{
Robert J. Gordon
}

Working Paper 7833

http://www.nber.org/papers/w7833

\author{
NATIONAL BUREAU OF ECONOMIC RESEARCH \\ 1050 Massachusetts Avenue \\ Cambridge, MA 02138 \\ August 2000
}

This research is supported by the National Science Foundation. I have benefitted from discussions on these topics with many people, especially Erik Brynjolfsson, Joel Mokyr, Jack Triplett, and the late Zvi Griliches. The views expressed herein are those of the authors and not necessarily those of the National Bureau of Economic Research.

(C) 2000 by Robert J.Gordon. All rights reserved. Short sections of text, not to exceed two paragraphs, may be quoted without explicit permission provided that full credit, including $(\mathbb{C}$ notice, is given to the source. 
Does the "New Economy" Measure up to the Great Inventions of the Past?

Robert J. Gordon

NBER Working Paper No. 7833

August 2000

JEL No. O30, O40, L63, L86

\section{$\underline{\text { ABSTRACT }}$}

During the four years 1995-99 U. S. productivity growth experienced a strong revival and achieved growth rates exceeding that of the "golden age" of 1913-72. Accordingly many observers have declared the "New Economy" (the Internet and the accompanying acceleration of technical change in computers and telecommunications) to be an Industrial Revolution equal in importance, or even more important, than the Second Industrial Revolution of 1860-1900 which gave us electricity, motor and air transport, motion pictures, radio, indoor plumbing, and made the golden age of productivity growth possible.

This paper raises doubts about the validity of this comparison with the Great Inventions of the past. It dissects the recent productivity revival and separates the revival of 1.35 percentage points (comparing 1995-99 with 1972-95) into 0.54 of an unsustainable cyclical effect and 0.81 points of acceleration in trend growth. The entire trend acceleration is attributed to faster multi-factor productivity (MFP) growth in the durable manufacturing sector, consisting of computers, peripherals, telecommunications, and other types of durables. There is no revival of productivity growth in the 88 percent of the private economy lying outside of durables; in fact when the contribution of massive investment in computers in the nondurable economy is subtracted, MFP growth outside of durables has actually decelerated.

The paper combines the Great Inventions of 1860-1900 into five "clusters" and shows how their development and diffusion in the first half of the 20th century created a fundamental transformation in the American standard of living from the "bad old days" of the late 19th century. In comparison, computers and the Internet fall short. The rapid decline in the cost of computer power means that the marginal utility of computer characteristics like speed and memory has fallen rapidly as well, implying that the greatest contributions of computers lie in the past, not in the future.

The Internet fails the hurdle test as a Great Invention on several counts. First, the invention of the Internet has not boosted the growth in the demand for computers; all of that growth can be interpreted simply as the same unit-elastic response to the decline in computer prices as was 
prevalent prior to 1995. Second, the Internet provides information and entertainment more cheaply and conveniently than before, but much of its use involves substitution of existing activities from one medium to another. Third, much internet investment involves defense of market share by existing companies like Borders Books faced with the rise of Amazon; social returns are less than private returns. Fourth, much Internet activity duplicates existing activity like mail order catalogues, but the latter have not faded away; the usage of paper is rising, not falling. Finally, much Internet activity, like daytime e-trading, involves an increase in the fraction of work time involving consumption on the job.

Robert J. Gordon

Department of Economics

Northwestern University

Evanston IL 60208-2600

and NBER

rjg@nwu.edu 


\section{TABLE OF CONTENTS}

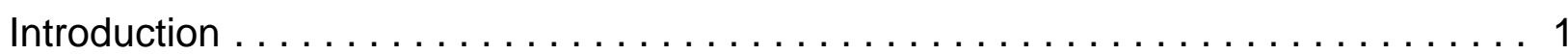

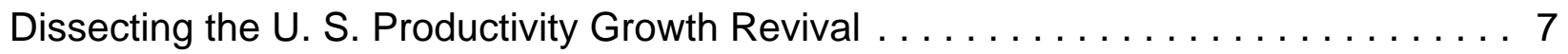

The "Direct" and "Spillover" Effects of the New Economy ........... . 8

The Productivity Growth Revival in Historical Perspective . . . . . . . . . . 10

Where Has the Revival Occurred and Can It Persist? . . . . . . . . 13

How the Great Inventions Helped Us Escape from the Bad Old Days . . . . . . . . 18

Life in the "Bad Old Days" . . . . . . . . . . . . . . . . . . . . . . . 19

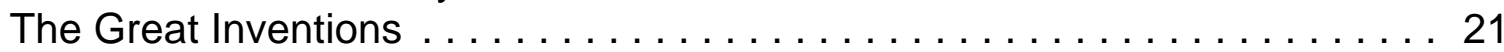

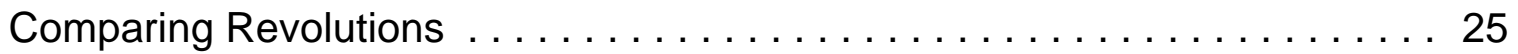

The Declining Cost of Computer Power and the Pervasiveness of

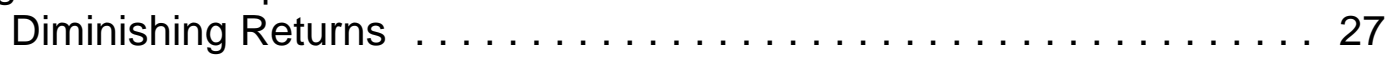

The Declining Cost of Computer Power ................. 28

Declining Computer Cost Confronts the Fundamental Limitation of Time . . . 30

Diminishing Returns and the David "Delay Hypothesis" . . . . . . . . 32

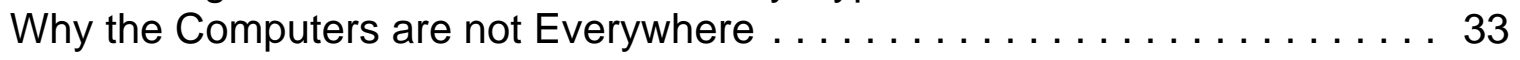

The Positive and Negative Side of the Internet . . . . . . . . . . . . . . 35

The Apparent Absence of a Rightward Shift in Demand . . . . . . . . . 36

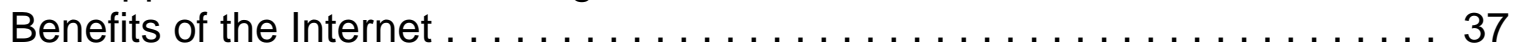

Qualifying the Benefit: Numbers of Products and a Fixed Time Endowment . 40

Why Isn't the Internet More Productive? . . . . . . . . . . . . . . 42

A Possible Qualification: Mismeasurement . . . . . . . . . . . . . 47

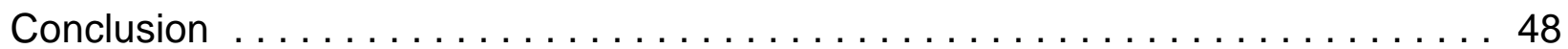

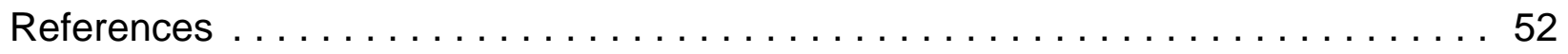

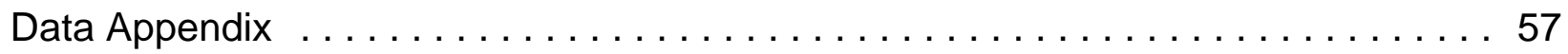

Tables

Figures

(Supplement) The Greatest Decade: The Honor Roll of Inventions, 1876-86 
"The invention of the semiconductor transistor set in motion a technological revolution that is arguably even more impressive and pervasive than that of the Great Industrial Revolution of the last century." -- Flamm (1997, p. 1)

"The chip has transformed us at least as pervasively as the internal-combustion engine or electric motor" -Fortune magazine, June 8, 1998, pp. 86-87.

The miracle of U. S. economic performance in the late 1990s was a source of pride at home, of envy abroad, and of puzzlement among economists and policymakers. ${ }^{1}$ The Federal Reserve presided over rates of output growth believed only a few years earlier to be unachievable even for a few quarters, much less over the four glowing years 1996-99. As the unemployment rate inched ever lower, the Fed reacted with benign neglect, so that early in the year 2000 short-term interest rates were no higher than they had been five years earlier and long-term interest rates were considerably lower.

Underneath it all lay the apparent demise, whether temporary or permanent, of two relationships that had restrained economic performance for the 25 years prior to 1996, Phillips' curve and Solow's paradox. Whatever had prevented "core" inflation rates from accelerating in the face of steadily falling unemployment — whether a set of beneficial shocks or a flattening of the Phillips curve itself - there was no doubt that low inflation had allowed the Fed to keep a set of loose reins on the galloping economic racehorse. ${ }^{2}$ And economists struggling to explain Solow's paradox — that "we can see the computer age everywhere except in the productivity statistics" — looked up from

1. Lawrence Summers spoke for many economists and policymakers recently when he characterized this widespread puzzlement as "paradigm uncertainty." See Business Week, "The Economy: A Higher Safe Speed Limit," April 10, 2000, p. 242.

2. Accessible articles on the sources of low inflation and the debate about shifts in the inflation-unemployment relationship include Gordon $(1997,1998)$ and Stock's discussion of the latter paper, Stock and Watson (1997), and Katz and Krueger (1999). The mirror image of the 1970s, when everything went wrong, and the 1990s, when everything went right, suggests that adverse supply shocks shifted the Phillips curve in an unfavorable direction in the earlier decade and in the opposite favorable direction in the latter decade (see Gordon, 2000a, pp. 263-269). 


\section{Industrial Revolution, Page 2}

their word processors to discover that, before they had satisfactorily explained it, the paradox had been rendered obsolete both by data revisions and by the exploding rates of productivity growth registered in 1998 and $1999 .{ }^{3}$ Suddenly the economy was awash not only in computers, but also in productivity growth, and in turn the rapid productivity growth helped to explain how inflation could remain low despite some evidence of accelerating wage rates. ${ }^{4}$

Since computer prices have been declining at rapid rates for the last fifty years, the nowstandard phrase "New Economy" applied to the period since 1995 must mean something more than declining computer prices and exponential growth in computer capabilities. We shall take the phrase to encompass a mid-1990s acceleration in the rate of price decline in computer hardware, software, and telephone services, the corollary of an acceleration of the exponential growth rate of computer power and telecommunications capability, and the wildfire speed of development of the Internet. As shorthand, we shall take the New Economy to be synonomous with an acceleration in rate of technical advance in Information Technology, commonly abbreviated IT. This interpretation means that we do not include in the New Economy the contributions made by IT prior to 1995 at the previous slower rate of technical advance, and hence the recent literature on the contributions of IT to business profits and productivity prior to 1995 is not directly relevant here. ${ }^{5}$

A widespread consensus has emerged that the New Economy represents a fundamental

3. Solow's first published recognition that the paradox is obsolete appears in Uchitelle (2000).

4. The Economic Report of the President, February 2000, pp. 90-91, presents a particularly insightful analysis of the mechanism by which an unexpected acceleration of productivity growth can, for a substantial period, reduce the inflation rate associated with any given unemployment rate.

5. See especially Brynjolfsson (1996), Brynjolfsson and Hitt (1996), and Brynjolfsson, Hitt, and Yang (2000). 


\section{Industrial Revolution, Page 3}

transformation, simultaneously wiping out in one fell swoop inflation, the budget deficit, the 1972-95 productivity slowdown, and the business cycle. ${ }^{6}$ The acceleration in productivity growth dates from the end of 1995, and Business Week showed remarkable prescience at that time in a cover banner titled "Productivity to the Rescue" and more recently declared "At least for now, even formerly skeptical forecasters and economists have acknowledged the reality of the productivity revolution." Among the leaders of the technological enthusiasts is Alan Greenspan, who recently stated "A perceptible quickening in the pace at which technological innovations are applied argues for the hypothesis that the recent acceleration in labor productivity is not just a cyclical phenomenon or a statistical aberration, but reflects, at least in part, a more deep-seated, still developing, shift in our economic landscape." ${ }^{8}$

The sudden revival of productivity growth, after years in which Solow's paradox accurately captured the lack of productivity payoff from computers, appears to vindicate Paul David (1990), who predicted that the benefits of computers were being delayed, just as were the benefits of electric motors at the turn of the century, but after some period would finally begin to boost economywide productivity just as electric motors caused a productivity acceleration in U. S. manufacturing in the 1920s. Accordingly, the enthusiasts treat the New Economy as a fundamental industrial revolution as great or greater in importance than the concurrence of inventions, particularly electricity and the

6. A typical unqualified comment is that "when it comes to technology, even the most bearish analysts agree the microchip and Internet are changing almost everything in the economy" (Ip, 2000).

7. The full Business Week cover title on October 9, 1995, was "Productivity to the Rescue: Technology is Transforming the American Economy into the Most Productive in the World." The more recent quote is from a Business Week editorial, May 31, 1999, p. 190.

8. Speech given by Alan Greenspan at the Federal Reserve Bank of Chicago, May 6, 1999. 


\section{Industrial Revolution, Page 4}

internal combustion engine, which transformed the world at the turn of the last century.

Yet, without disputing the facts of the productivity revival and the broader miracle of the American economy, room remains for skepticism. Does the New Economy merit treatment as a basic Industrial Revolution of a magnitude and importance equivalent to the great inventions of the late 19th and early 20th century? These, particularly electricity and the internal combustion engine, but also including chemicals, movies, radio, and indoor plumbing set off 60 years between roughly 1913 and 1972 during which multi-factor productivity (hereafter MFP) growth grew more rapidly than before or since, and during which everyday life was entirely transformed.

The skeptic's case begins with a new interpretation of the recent productivity revival. While impressive on the surface, the revival reveals a marked imbalance in its location within the economy, appearing to be centered in the production of computer hardware, including peripherals, and telecommunications equipment, with substantial spillover to the rest of durable manufacturing. However, outside the 12 percent of the economy engaged in manufacturing durable goods, the New Economy's effects on productivity growth are surprisingly absent, and capital deepening has been remarkably unproductive. ${ }^{9}$

If Solow's computer paradox is still alive and well outside of durable manufacturing, where most of the computers are located, then we must probe deeper and ask why such a massive investment has yielded so little payoff. We begin with a historical retrospective on living conditions in the late 19th century, in order to understand how fundamental was the transformation achieved by

9. In 1996 current dollar value-added in durable manufacturing was 11.6 percent of current-dollar output in the nonfarm private business sector. See Economic Report of the President, February 1999, Tables B-10 and B-12. 


\section{Industrial Revolution, Page 5}

five clusters of inventions that occurred during the interval 1860-1900, hereafter to be called the "Great Inventions". In contrast to these earlier inventions, computers differ in the exponential rate of decline in the prices of computer speed and memory, which brings with it a massive substitution toward ever greater use of speed and memory. Set against this exponential increase in computer capability is a fixed endowment of time and a limited endowment of human brainpower, creating diminishing returns at a rate never before seen in economic history as the supply curve of computer power shifts down a relatively fixed demand curve.

It is often assumed that the invention of the Internet in the mid-1990s shifted the demand curve to the right, thus ending or postponing the rapid onset of diminishing returns. Accordingly, if the Internet was the important invention that many assume, the growth in the demand for computer power should have accelerated after 1995 relative to the rate of decline in price. But our examination of aggregate data on the price and quantity of computer characteristics rejects this assumption; the response of computer quantity to the decline in computer price was much larger before 1987 than afterwards and did not accelerate after 1995. In fact, we shall argue the opposite of the David "delay" hypothesis; the speed at which diminishing returns have taken hold makes it likely that the greatest benefits of computers lie a decade or more in the past, not in the future.

The paper then explores some of the limitations of the computer in general and the Internet in particular when evaluated in comparison with the Great Inventions of the past. Computers are less pervasive than is generally thought, because there are real limitations to the replacement of human beings by computers. Many jobs require hand-and-eye coordination, and in the services many occupations inherently require face-to-face contact between human beings or between a human 
worker and an object.

Similarly, the number of new companies and new products associated with the Internet is not as impressive as it may appear, because the economy today is much larger now than at the time of the Great Inventions and requires many more innovations per year to achieve the same proportional growth rate in technology and productivity.

Five factors are examined that help to explain why the Internet has had so minimal an impact, at least thus far, on productivity growth outside of durable manufacturing. First, consumer time is limited, so much of Internet use simply substitutes for other forms of entertainment and information gathering, such as watching TV, playing handheld games, and going to the public library. Second, much investment in Internet web sites and infrastructure represents competition for market share which redistributes sales rather than creating them, as when Borders and Barnes and Noble struggle to defend themselves against the rise of Amazon.com. Third, much internet content is not truly new, but rather consists of preexisting forms of information now made available more cheaply and conveniently, in contrast to the sense in which the Great Inventions created truly new products and activities. Fourth, much web site development duplicates rather than replaces existing forms of commerce and information, raising costs more than revenue. Fifth, there is growing evidence that a large fraction of consumption activity on the web takes place at the office, where workers take advantage of fast broadband web access at the expense of their employers.

\section{Dissecting the U. S. Productivity Growth Revival}

To assess the role of computers in the recent productivity growth revival, we need to 


\section{Industrial Revolution, Page 7}

distinguish between the growth rates of average labor productivity (ALP) and multi-factor productivity (MFP). The former compares output growth $(y)$ with that of a single input, labor hours (h), while the latter compares output with a weighted average of several inputs, including labor, capital $(k)$, and sometimes others, including materials, energy, and/or imports. The two concepts can be related by considering a simple production function relating the growth rates of output and two inputs, labor and capital:

$$
y=m+b h+(1-b) k
$$

where $m$ is the growth rate of MFP, $b$ is the elasticity of output with respect to labor input, and (invoking constant returns to scale) $1-b$ is the elasticity of output with respect to capital input. Equation (1) states that output growth is the sum of MFP growth and of the separate contributions of labor and capital input, weighted by the elasticity of output growth to each input.

Equation (1) can be easily transformed to relate the growth in ALP to the growth in MFP:

$$
y-h=m+(1-b)(k-h)
$$

Now we see that growth in ALP or output per hour $(y-h)$ is equal to growth in MFP $(m)$ plus the contribution of "capital deepening," that is, the elasticity of output with respect to capital $(1-b)$ times the growth rate of the capital-labor ratio $(k-h)$.

\section{The "Direct" and "Spillover" Effects of the New Economy}


Industrial Revolution, Page 8

We can use equation (2) to examine the effects of computers and the New Economy on the recent productivity growth revival. Imagine a spontaneous acceleration in the rate of technological change in the computer sector, which induces a more rapid rate of decline in computer prices and an investment boom as firms respond to cheaper computer prices by buying more computers. ${ }^{10}$ In response, since computers are part of output, this acceleration of technical change in computer production raises the growth rate of $\mathrm{MFP}(m)$ in the total economy, boosting the growth rate of ALP $(y-h)$ one-for-one. Second, the ensuing investment boom raises the magnitude of the capital deepening term $(1-b)(k-h)$, thus increasing the growth in ALP relative to MFP.

In discussing the New Economy, it is important to separate the computer-producing sector from the computer-using sector. No one denies that there has been a marked acceleration of output and productivity growth in the production of computer hardware, including peripherals. ${ }^{11}$ The real issue has been the response of productivity to massive computer investment by the 96 percent of the economy engaged in using computers rather than producing them. ${ }^{12}$ Applying (2) to the "noncomputer" economy, i.e., the portion of the economy not directly engaged in making computer

10. In the U. S. national accounts computer prices are measured by the hedonic regression technique, in which the prices of a variety of models of computers are explained by the quantity of computer characteristics and by the passage of time. Thus the phrase in the text "decline in computer prices" is shorthand for "a decline in the prices of computer attributes like speed, memory, disk drive access speed and capacity, presence of a CD-ROM, etc."

11. In this paper we emphasize computer hardware, rather than the universe of computer hardware, software, and telecommunications equipment, because the BEA deflators for software and telecommunications equipment are problematic, exhibiting implausibly low rates of price decline, as argued by Jorgenson and Stiroh (2000).

12. In 1999 nominal final sales of computers and peripherals plus fixed investment in software represented 3.5 percent of nominal GDP in the nonfarm nonhousing private business economy. Thus the "non-computer part of the economy" represents 96.5 percent of nonfarm nonhousing private business output. Final sales of computer hardware is an unpublished series obtained from Christian Ehemann of the BEA; the other series in this calculation appear in the Economic Report of the President, February 2000, Tables B-10 and B-16. 


\section{Industrial Revolution, Page 9}

hardware and software, we might see two types of effects of computers. If the only effect of the technological breakthrough in computer production on the non-computer economy is an investment boom that accelerates the growth rate of capital input, then non-computer ALP growth would rise by the capital-deepening effect $(1-b)(k-n)$, but there would be no increase in non-computer MFP growth. Let us call this the "direct" effect of the New Economy on the non-computer sector. Sometimes advocates of the revolutionary nature of the New Economy imply that computer investment has a higher rate of return than other types of investment and creates "spillover" effects on business practices and productivity in the non-computer economy; evidence of this "spillover" effect would be an acceleration in MFP growth in the non-computer economy occurring at the same time as the technological acceleration in computer production.

The distinction between the direct and spillover effect is illustrated in Figure 1, which refers to the non-computer sector and plots the growth rate of output per hour $(y-h)$ against that of capital per hour $(k-h)$. Points in the graph contrast growth rates for 1972-95 and 1995-99, the periods of the productivity growth slowdown and revival, respectively. The lowest line labelled "capital-deepening effect" represents the term $(1-b)(k-h)$ in equation (2) and uses a typical value of one-third for the elasticity $(1-b)$. The line labelled "direct effect only" assumes that there is no change in MFP growth in the non-computer sector in 1995-99 (point $\mathrm{A}^{\prime}$ ) compared with 1972-95 (point A) from the previous rate labelled $m_{A}$. The top line labeled "with spillover effect" assumes that computer investment has created spillover effects in the non-computer sector that raises MFP growth from $m_{A}$ to $m_{B}$ for the 1995-99 period, as at point B. In our subsequent examination of the data, we will look for evidence that the New 
Economy has created spillover effects in the non-computer sector.

\section{The Productivity Growth Revival in Historical Perspective}

What is the counterpart of the New Economy in the official output data? As shown in the top frame of Figure 2, the remarkable event which occurred at the end of 1995 was an acceleration of the rate of price change in computer hardware (including peripherals) from an average rate of -14.7 percent during 1987-95 to an average rate of -31.2 percent during 1996-99. ${ }^{13}$ Computers did not become more important as a share of dollar spending in the economy, which stagnated at around 1.3 percent of the nonfarm private business economy, as shown in the bottom frame of Figure 2. The counterpart of the post-1995 acceleration in the rate of price decline was an acceleration in the rate of technological progress; apparently the time cycle of Moore's Law shortened from 18 months to 12 months at about the same time. ${ }^{14}$

On the surface, the productivity growth revival which began at the end of 1995 is impressive, especially when set in a historical context, and it suggests that substantial direct and spillover effects of computer investment may have occurred in the non-computer sector. First we examine the basic facts for the aggregate economy from the perspective of more than a century and postpone until the

13. One way of dramatizing the rate of price decline is to translate it into the ratio of performance to price when 1999:Q4 is compared with 1993:Q4. The BEA's implicit deflator for computer final sales implies an improvement over that six-year period by a factor of 5.2. Improvements in performance-price ratios for individual computer components are substantially larger, by a factor of 16.2 for computer processors, 75.5 for RAM, and 176.0 for hard disk capacity. See "Computers, then and now," Consumer Reports, May, 2000, p. 10, where the published reported comparisons in 1999 dollars have been converted to nominal dollars using the Consumer Price Index.

14. This fact is based on a conversation between Gordon Moore and Dale W. Jorgenson, related to the author by the latter. 


\section{Industrial Revolution, Page 11}

next section the decomposition of the economy into the computer and non-computer sectors. Table 1 compares rates of output, input, and productivity growth achieved in the American economy during the four years 1995-99 as compared with three long intervals going back to $1870 .{ }^{15}$ The table is divided into three sections: line 1 exhibits the growth rate of nonfarm nonhousing output, lines 2-5 exhibit growth rates of inputs and productivity for labor and capital inputs as conventionally measured, and lines 6-9 are based on alternative input concepts which are adjusted for changes in composition, e.g., the shift in labor input along the dimensions of age, sex, and educational attainment, and the shift in capital input from structures to equipment. ${ }^{16}$

The first three columns of Table 1 divide 125 years of history into three long intervals divided at 1913 and 1972. The pattern of growth rates displayed on line 6 for composition-unadjusted MFP can be summarized as "slow-fast-slow", which led me $(1999,2000 \mathrm{~b})$ to label this pattern as "one big wave" in the history of U. S. productivity growth. The composition-adjusted MFP growth rates displayed on line 11 show a lopsided wave with near-zero MFP growth in the 1972-95 period, considerably slower than in 1870-1913 and much slower than in 1913-72. In the past I have pointed to this wave-like pattern as suggesting that the basic question about historical productivity growth should not be "why was growth was so slow after 1972?" but rather "why was growth was so fast

15. The record compiled for 1870-1996 in Table 1 is based on Gordon (2000b), which merges data from Kendrick (1961) with BEA and BLS data for the postwar period and develops estimates for labor and capital composition to carry the postwar BLS composition adjustments back from 1948 to 1870.

16. The section in lines 2-6 that excludes the composition adjustments is included to allow comparability with the unadjusted quarterly data to be examined in Table 2 in the next section. Likewise housing is excluded to retain comparability with Table 2. Adjustments for labor composition were pioneered by Griliches (1960) and Denison (1962), and for capital composition by Jorgenson and Griliches (1967). Similar adjustments are incorporated in the official BLS series on MFP that currently cover 1948-97, and detailed annual data are available through 1998 in Jorgenson and Stiroh (2000). 


\section{Industrial Revolution, Page 12}

during the golden years 1913-72?" I have attributed the outstanding performance of the golden years to the role of the Great Inventions discussed below.

But waves inherently repeat themselves, and the data for 1995-99 are consistent with the beginning of a new golden age of productivity growth. Either with or without composition adjustments, MFP growth during 1995-99 exceeded that in the golden age period. Growth in output per hour by either measure in lines 5 or 10 exceeded that in the golden age by a much larger amount, since capital deepening during 1995-99 proceeded at such a rapid rate. The revival of ALP growth was so extraordinary that, after we account for the major contribution of capital deepening, there was still room for MFP growth to accelerate by more than a full percentage point on both lines 6 and 11 .

\section{Where Has the Revival Occurred and Can it Persist?}

Thus far it would appear that the glowing optimism of New Economy advocates is well deserved, and that computers and the internet have brought U. S. productivity growth out of its twodecade doldrums into another golden age. Yet there is still room for doubt for two reasons. First, a major fraction of the revival in MFP growth has occurred within the small part of the economy engaged in producing computers and peripherals, and within the rest of the durable manufacturing sector. When durable manufacturing is stripped out from the data, the extent of the revival is much diminished. Second, there is a large literature on the procyclicality of productivity supporting the view that productivity grows unusually rapidly when output grows faster than its trend. Growth in U. S. output during 1995-99 was faster than the sustainable trend, a growth surge made possible in part by two unsustainable "safety valves" (Alan Greenspan's phrase), a decline in the unemployment 


\section{Industrial Revolution, Page 13}

rate from 5.6 percent to 4.2 percent, and an increase in the current-account deficit from 1.5 to 3.9 percent of GDP. ${ }^{17}$ If output was growing faster than trend, then productivity was also growing faster than trend, and some part of the productivity revival recorded in Table 1 was transitory rather than permanent. In the words of the Wall Street Journal, "only the most starry-eyed New Economy believers thinks that the 7\% annualized pace set in last year's [1999] fourth quarter is sustainable" (Schlesinger and Dreazen, 2000).

This section provides a brief summary of a more extensive cyclical analysis provided in Gordon (2000c), based on quarterly BLS data for output and hours. Quarterly data is used in an econometric analysis that decomposes the growth in labor productivity $(y-h)$ into trend and cyclical components separately for the nonfarm private business (NFPB) sector and that sector excluding durable manufacturing (hereafter NFND). ${ }^{18}$

The idea that productivity varies procyclically dates back to Hultgren (1960) and "Okun's Law" (Okun, 1962) and was first interpreted by Oi (1962), who described labor as a "quasi-fixed factor" that adjusts only partially during cyclical swings of output. ${ }^{19}$ In my econometric specification, the change in the growth of actual hours relative to the hours trend $\left(h-h^{*}\right)$ is explained by changes

17. MEMO: 1999 figure is for 1999:Q3, annualized. This number is to be updated.

18. The quarterly BLS productivity data cover four sectors - NFPB, durable manufacturing, nondurable manufacturing, and nonfinancial corporations. In this paper to save space we limit our attention only to NFPB and durable manufacturing, including nondurable manufacturing in the residual NFND sector.

19. Citations to the modern literature on the procyclicality of "Solow's residual", i.e., MFP, can be found in Basu (1996). 


\section{Industrial Revolution, Page 14}

in its own lagged values and by changes in the growth of output relative to trend $(y-y *){ }^{20}$ Hours growth lags behind output growth and responds by roughly 0.75 of the output change; thus growth in output per hour $(y-h)$ exhibits a temporary acceleration when hours are lagging behind output changes, and in addition increases by roughly 0.25 of any excess in output growth relative to trend.

The decomposition of the recent productivity acceleration between cycle and trend is accomplished by specifying a value for the hours growth trend $\left(h^{*}\right)$ and then conducting a grid search to find the output growth trend $\left(y^{*}\right)$ that optimizes the fit of the equation explaining the relation of $h-h *$ to $y-y *{ }^{21}$ The results displayed in Table 2 allow us to assess the direct and spillover effects of computers on output per hour and MFP growth during the period between 1995:Q4 and 1999:Q4. The first column refers to the aggregate economy, i.e., the NFPB sector including computers. Of the actual 2.82 percent annual growth of output per hour, 0.54 is attributed to a cyclical effect and the remaining 2.28 percent to trend growth, and the latter is 0.81 points faster than the $1972-95$ trend. How can this acceleration be explained? A small part on lines 6 and 7 is attributed to changes in price measurement methods and to a slight acceleration in the growth of labor quality. ${ }^{22}$ The remaining

\footnotetext{
20. The recent research (Gordon, 2000c) updates the cyclical analysis of labor productivity contained in Gordon (1993).

21. It is assumed that actual and trend output were equal in 1954:Q1, 1963:Q3, 1972:Q2, 1978:Q2, 1987:Q3, and 1995:Q4. The task is to determine the optimal output trend after 1995:Q4. The regression equation is estimated for the period 1954:Q1-1999:Q4, and the growth in trend output is varied to minimize the root-mean-squared error over 1996:Q1-1999:Q4. The hours trend is set at a rate consistent with a NAIRU (non-accelerating inflation rate of unemployment) in 1999:Q4 of 5.0 percent. A more optimistic NAIRU of 4.5 percent would yield a trend that is 0.11 points faster on line 4 of Table 2, changing the results on subsequent lines correspondingly.
}

22. The price measurement effect consists of two components. While most changes in price measurement methods in the CPI have been backcast in the national accounts to 1978, one remaining change — the 1993-94 shift in medical care deflation from the CPI to the slower-growing PPI - creates a measurement discontinuity of 0.09 percent. The fact that other measurement changes were carried back to 1978 rather than 1972 creates a further 


\section{Industrial Revolution, Page 15}

0.62 points can be directly attributed to computers. The capital-deepening effect of faster growth in capital relative to labor in the aggregate economy accounts of 0.33 percentage points of the acceleration (all due to computers), and an acceleration of MFP growth in computer and computerrelated semiconductor manufacturing account for all of the rest. ${ }^{23}$ Nothing is left for a structural acceleration in MFP outside of the computer-producing sector. Thus in terms of Figure 1, the noncomputer economy is at a point like $A^{\prime}$, reflecting the effect of capital-deepening on growth in output per hour but retaining the same structural growth trend of $\operatorname{MFP}\left(m_{A}\right)$ as before 1995.

A different way of assessing the role of computers is displayed in the second column of Table 2. Here we subtract output and hours in computer manufacturing from the NFPB economy and find that the structural acceleration of labor productivity on line 8 is 0.43 percentage points, compared to 0.62 for the total NFPB economy. Line 11 indicates a small structural deceleration in MFP of 0.09 points. ${ }^{24}$ Thus far we conclude that the impact of capital deepening has created a genuine revival in growth in output per hour (ALP) in the non-computer economy but that spillover effects on MFP in the non-computer economy are absent (column 1) or slightly negative (column 2).

22. (...continued)

discontinuity of 0.05 when the full 1972-95 period is compared to 1995-99. The acceleration in labor quality growth reflects the same compositional changes discussed in connection with Table 1 above; labor quality growth during 197295 was held down by a compositional shift toward female and teenage workers during the first half of that period.

23. In the Oliner-Sichel decomposition on which line 9 is based, computers account for all of the acceleration in the capital-deepening effect, and the additional acceleration attributable to semiconductors and telecommunications is exactly canceled out by a deceleration of capital deepening for all other types of equipment and structures (See Oliner and Sichel, Table 2, lines 2 through 7.

24. The main explanation of the difference on line 11 in the first two columns is that the first column subtracts out MFP growth in computers and computer-related semiconductors, while the second column subtracts out only computers but not computer-related semiconductors. This inconsistency is imposed by the data available in the Oliner-Sichel (2000) source. 


\section{Industrial Revolution, Page 16}

However, this conclusion is far too optimistic regarding the effect of computers outside of durable manufacturing, i.e., the NFND sector examined in the final column of Table 2. Starting from a much lower actual growth rate of 2.05 percent, a slightly larger cyclical effect is subtracted, leaving an acceleration in trend on line 5 of only 0.24 percent. ${ }^{25}$ Almost all of this can be explained by price measurement and labor quality, leaving a structural acceleration in output per hour growth of only 0.05 percent, far less than is accounted for by capital deepening (line 9). As a result, line 11 shows that there has been a substantial structural deceleration in MFP growth in the NFND sector.

Figure 3 summarizes the results in this section by decomposing the post-1995 acceleration in ALP growth of 1.35 percent among its components. The "New Economy" is alive and well, but only within computer manufacturing and the remainder of the manufacturing durable sector. The right-hand bar shows the deceleration in MFP growth in the NFND sector. This surprising finding can be interpreted either as a "literal" deceleration in MFP growth compared to the 1972-95 period or as suggesting that the acceleration of computer investment has had a negligible payoff, implying a near-zero rate of return of computer investment outside of durable manufacturing. How could there be such a low payoff to computer investment in most of the economy where the vast majority of the computers are located $?^{26}$ In this sense the Solow computer paradox survives intact for most

25. There is no cyclical effect in durable or nondurable manufacturing; this is the corollary of the absence of any increase in the capacity utilization rate in manufacturing and of the absence of any acceleration in hours growth in manufacturing between 1995 and 1999. Thus the cyclical effect occurs entirely outside of manufacturing, accounting for the higher cyclical effect when durables are stripped out in Table 2, column 3.

26. McGuckin and Stiroh (1998, Table 1, p. 42) show that 88.5 percent of the computers are used in eight of the 34 industries in their data base for the U. S. private economy. 76.6 percent are used in Trade, FinanceInsurance-Real Estate, and Other Services, while 11.9 percent are used in five computer-intensive industries within manufacturing, and only 11.5 percent in the remaining 27 industries. 
Industrial Revolution, Page 17

of the economy, and the need to explain it motivates the rest of this paper.

\section{How the Great Inventions Helped Us Escape from the Bad Old Days}

Our central theme is that computers and the internet do not measure up to the Great Inventions of the late nineteenth and early twentieth century, and in this sense do not merit the label of "Industrial Revolution". In this sense we are using the common definition of an Industrial Revolution as applying to any great acceleration of output and productivity growth that is pervasive and economywide, and our skepticism is based on the apparent failure of computers and the internet to achieve a breakthrough in either ALP or MFP growth outside of durable manufacturing. ${ }^{27}$ Our comparison is not with the First Industrial Revolution in Britain during 17601830 but with what is sometimes called the Second Industrial Revolution, which took place simultaneously in Europe and the United States and can be dated roughly $1860-1900 .^{28,29}$ As we learned in Table 1, it was the Second Industrial Revolution, not the first, that created the golden age

27. "Usage of the term spread from 'the' Industrial Revolution (that of Great Britain, roughly between 1760 and 1830), to a general expression, to be applied to any great acceleration of industrial output wherever it may occur" (Checkland, 1987, p. 811). "There are different ways to judge technological breakthroughs; the obvious one and most appealing to economists is the impact on output and productivity" (Mokyr, 1997, p. 33).

28. For such a comparison see Mokyr (1997, p. 33), who writes in this context that "One can judge an era of technological advances by whether it is one of door-opening or gap-filling inventions. It could be argued that if the criterion for an Industrial Revolution is a cluster of such macroenventions, this does qualify our age as much as the classical British Industrial Revolution, but so does the period roughly between 1860 and 1900."

29. Also, what is being compared is not the entirety of technological advance of the 1990s but only the role of the computer and the internet; a broader perspective that included biology, pharmaceuticals, and medical technology might lead to a more sympathetic comparison of recent progress with the Second Industrial Revolution. However, the yearly rate of increase in life expectancy at birth during 1900-1950, resulting in substantial part from the inventions of the Second Industrial Revolution, was 0.72 percent per year, triple the 0.24 percent annual rate during 1950-95. See Nordhaus (1999), Figure 3. 


\section{Industrial Revolution, Page 18}

of productivity growth. Indeed, MFP grew at a snail's pace in the nineteenth century; as Brad DeLong has observed "Compared to the pace of ecnomic growth in the 20th century, all other centuries — even the 19th ... — - were standing still." ${ }^{130}$ To understand the profound sense in which the Great Inventions of the Second Industrial Revolution altered the standard of living of the average American resident during the golden age, we begin with a brief tour of some of the less desirable aspects of living in the late nineteenth century.

\section{Life in the "Bad Old Days"}

An eye-opening introduction to the conditions of that era is provided in a little-known book by Otto Bettman (1974), the founder of the famed Bettman photographic archive. Bettmann divides the horrors of the past into eleven categories, which for brevity will be condensed into four.

Air, Food, Drink, and Health. The urban streets of the 1870s and 1880s were full not just of horses but pigs, which roamed the streets and were tolerated because they ate garbage. In Kansas City, the confusion and stench of patrolling hogs were so penetrating that Oscar Wilde observed, "They made granite eyes weep." The steadily increasing production of animal waste caused the more pessimistic observers to fear that American cities would disappear like Pompeii — but not under ashes. Added to that was acrid industrial smog, sidewalks piled high with kitchen slops, coal dust, and dumped merchandise, which became stirred together in slime after a rain. All of this was made worse in the summer, which was almost as unbearable outdoors as inside, especially with the heavy

30. Quoted in "A Century of Progress," Economist, April 15, 2000, p. 86. [ED: Citation to original DeLong WP to be substituted when I obtain the WP]. 
clothes of the day. Rudyard Kipling said of Chicago, "Having seen it, I desire urgently never to see it again. Its air is dirt." Added to putrid air was the danger of spoiled food - imagine unrefrigerated meat and poultry hung unrefrigerated for days, spoiled fruit, bacteria-infected milk, and virtually all types of food were suspected of adulteration. Epidemics included yellow fever, scarlet fever, and smallpox. The pain and lack of sanitation in surgery were endemic, and many hospitals were deathtraps.

Motive Power. Before the invention of electricity, urban streets were a chaotic jungle of horse trolleys, and horse-drawn conveyances of all types, made even more congested in winter by horse-drawn snowplows that did little more than move the snow out of the way of the trolleys by dumping it on the sidewalks. Rural life was also no picnic; among its features were isolation, loneliness, and the drudgery of fireplace cooking and laundry done by muscle-power. Travel between cities on railroads was surprisingly dangerous; in 1890 railroad-connected accidents caused 10,000 deaths. Emigrants traveled west on wooden benches in worn-out boxcars attached to freight or cattle trains.

Housing. In 1882 only two percent of New York City's houses had water connections. Urban apartments were crowded, damp, airless, and often firetraps. Even middle-class apartment buildings were little more than glorified tenements; families were shelved in layers, with no insulation from the neighbors' cooking smells or babies' squallings. In the slums as many as eight persons shared a single small room.

Working Conditions. Those who have seen the movie "Titanic" may have shared my momentary shock at the working conditions of the sweating laborers shoveling coal into the huge 
Industrial Revolution, Page 20

mouths of the ship's boilers. Coal miners, steel workers, and many others worked 60-hour weeks in dirty and dangerous conditions, exposed to suffocating gas and smoke. Danger was not confined to mines or mills; in 1890 one railroad employee was killed for every 300 employed. ${ }^{31}$ Sewing in a sweatshop might have been the most oppressive occupation for women but was not as dangerous as soap-packing plants or the manual stripping of tobacco leaves. ${ }^{32}$

\section{The Great Inventions}

The transition from these often abysmal living conditions to today's much easier and more pleasant life resulted from the complex interaction of ideas, inventions, and the feedback from growing wealth that allowed poor families to live as well or better in many aspects of life than the wealthy of one hundred years earlier. While there many individual inventions, it helps to group them together into five "clusters" or groups that can be compared with the cluster of inventions in computer hardware, software, and telecommunications equipment now commonly called the "New Economy." Each of these clusters had a primary breakthrough invention that occurred during the period $1860-1900 .{ }^{33}$

31. Thus in the single year of 1890 there were 10,000 deaths by passengers in railroad-connected accidents and 2450 deaths by workers in the American railroad system (Bettman, 1974, pp. 70, 171).

32. Except for the "Titanic" remark, everything in the preceding four paragraphs consists of a mix of paraphrases and quotes from Bettman (1974).

33. "Many inventions that mark the technological development of the 20th century were put in place during the last two decades of the 19th century: the telephone, electric generator, electric light, steam turbine, cheaper processes for making steel and aluminum, automatic machine tools, and most important in its effect on society, the internal combustion engine" (Bunch and Hellemans, 1993, p. 278). Omitted from this list are the invention of paper roll film by George Eastman and of the motion picture by Thomas A. Edison and William Dickson in the same year (1888) and of the phonograph by Edison in 1879. The typewriter was patented in 1868 and reached "its modern form in the 1890s" (Sichel, 1997, p. 123); see also Cortada (1993). These two sources also indicate that many types of office machines, including four-function calculators, mimeograph machines, and punch-card sorters, date from the 1880s 


\section{Industrial Revolution, Page 21}

(1) The first great invention in the "Group of Five" is electricity, including both electric light and electric motors, which dates from the simultaneous invention of the electric light bulb in 1879 by Thomas A. Edison in the U. S. and by Joseph W. Swan in England, and the first power station in 1882. As shown by Nordhaus (1997), electricity drastically reduced the price of a lumen of light. Electric motors, after a developmental period of two or more decades emphasized by David (1990), revolutionized manufacturing by decentralizing the source of power and making possible flexible and portable tools and machines. After a somewhat longer lag, electric motors embodied in consumer appliances eliminated the greatest source of drudgery of all, manual laundry; through refrigeration virtually eliminated food spoilage; and through air conditioning made summers enjoyable and opened the southern United States for modern economic development. ${ }^{34}$

(2) Sharing the title with electricity for the most important invention that had its main diffusion in the twentieth century is the internal combustion engine, which made possible personal autos, motor transport, and air transport. ${ }^{35}$ Grouped in this category are such derivative inventions as the suburb, highway, and supermarket. ${ }^{36}$ Gradually eliminated or greatly reduced were many of the ills of the late nineteenth century, from manure to unplowed snow to rural isolation.

33. (...continued)

and 1890s. See Sichel (1997, pp. 121-7).

34. See Oi (1997) for an insightful analysis of the effect of air conditioning on productivity.

35. The first internal combustion engine operating on modern principles is attributed to Julius Hock in 1870 and the first four-cycle engine to Nikolaus Otto in 1877. The first high-speed engine was built by Gottlieb Daimler in 1883 and the first three-wheeled automobile by Karl Benz in 1885. See Bunch and Hellemans (1993), pp. 268-93.

36. Bresnahan and Gordon (1997) in their introduction provide a formal analysis of how complementary inventions like supermarkets, suburbs, and highways increase the consumer surplus contributed by new inventions like the internal combustion engine and the motor car. 
(3) The third group of great inventions includes petroleum, natural gas, and various processes which "rearrange molecules," including chemicals, plastics, and pharmaceuticals. ${ }^{37}$ Some of these inventions were spontaneous and other were induced by the demands of motor and air transport. They helped to reduce air pollution created by industrial and heating uses of coal, and they made possible many new and improved materials and products, as well as conquering illness and prolonging life. Unlike the discontinuity created by the revolutionary impact of electricity and the internal combustion engine, the development of petroleum, chemicals, and their derivative industries was more of a continuous process dating from the mid-nineteenth century onwards.

(4) The fourth cluster consists of the complex of entertainment, communication, and information innovations that were developed before World War II. This set of inventions that made the world smaller (in a more profound sense than the Internet) can be traced back to the telegraph (1844) and includes the telephone (1876), phonograph (1877), popular photography (1880s and 1890s), radio (1899), motion pictures (1881 to 1888), and television (1911). ${ }^{38}$ Television is the only one of these innovations that was diffused into the popular marketplace after World War II. Otherwise, all the rest were well established before World War II and created a quantum leap in the standard of living when a year like, say, 1939 is compared with fifty years earlier. And this list does not even include the gradual diffusion over the nineteenth century of literacy and reading stimulated by the spread of inexpensive books and newspapers, the "penny post," and free public libraries.

37. My colleague Joel Mokyr dates the development of modern chemistry to the discovery of synthetic dye by William Perkin in 1856 and of the benzene molecule by August von Kekulé in 1865.

38. Dates of initial inventions are from Bunch and Hellemans (1993). 
(5) Perhaps the most tangible improvement in the everyday standard of living, besides electric light, came through the rapid spread after 1880 of running water, indoor plumbing, and urban sanitation infrastructure. The timing of this epochal development can be traced to "the first enunciation of the germ theory of disease by Louis Pasteur in 1864." ${ }^{139}$ Mokyr and Stein credit Pasteur's germ theory of disease for the great decline in mortality in the four decades prior to World War I, long before the invention of antibiotics, although in part the development of indoor plumbing was independent of the germ theory and dates to the contemporary invention of the indoor flush toilet. ${ }^{40}$

The "Group of Five" inventions, in turn, created an increase in per-capita income and wealth during the golden years of productivity growth (1913-72) that allowed an improvement in living standards even in those aspects of consumption where inventions did not play a major role, particularly the ability of families to afford many more square feet of shelter (and in the suburbs more land surrounding that shelter) than in 1880. Although we have grouped together our clusters of inventions for ease of discussion, our list is quite similar to the list of the "Greatest Engineering Achievements of the 20th Century" recently released by the National Academic of Engineering (NAE) and displayed in Table 3. The NAE list includes separate entries for 11 inventions that we have grouped together into our five clusters, and the links with our clusters are indicated in the table. Interestingly, eight of the top 10 on the NAE list appear on our list of inventions which had their genesis prior to the year 1900, and only two postwar inventions (electronics and computers) make

39. Mokyr and Stein (1997), p. 146.

40. The flush toilet was invented in 1886 by the infamously named Englishman Thomas Crapper. 
Industrial Revolution, Page 24

the top $10{ }^{41}$ The Internet, subject of so much New Economy "hype", is listed at a lowly 13th position.

\section{Comparing Revolutions}

Has the information revolution spawned by the computer created as great a change in living conditions as any of the five major clusters of early twentieth- century inventions? While retrospective exercises are inevitably subjective, it is interesting to play an expanded version of what I like to call the "New Yorker game." A few years ago the New Yorker commissioned a critic to sit in front a television set for an entire week and record his impressions. He had many reactions, but the one most relevant for us is that he was surprised from the reruns of $1950 \mathrm{TV}$ shows how similar were the living conditions of the 1950s Ozzie and Harriet families in comparison to those of today. Clearly living conditions were far better in the 1950s than in the 1890s, in large part because of the "Group of Five" inventions. We can surmise that a hypothetical critic revisiting the 1890s through a time machine would not have the same reaction that little had changed. Society had cured most of the ills of late nineteenth century living conditions by the 1950s without any help from computers. Among the achievements of the computerless society were the production miracle and the organization of 12 million people in the U. S. armed forces during World War II, achieved with a technology of typewriters, calculating machines, and file cards, and likewise the critical operation

41. It is debatable whether electronics or computers should be credited to the postwar era. Herman Hollerith developed punch card counting for the 1890 U. S. Census, founded the predecessor company of IBM in 1896, and developed the first numerical keyboard for punching cards in 1901. As for electronics, the photoelectric cell was invented in 1900 and the vacuum tube in 1904. 


\section{Industrial Revolution, Page 25}

"Ultra" which decoded the German Enigma code and was responsible for some of the most important intelligence breakthroughs and deceptions of the war.

To understand at a deeper level why the computer revolution does not measure up to the earlier great inventions, it is useful to consider some of the ways in which the great inventions created productivity growth. Electric light was a unique invention that extended the length of the day for reading, entertainment, and other pursuits. Both the electric motor and internal combustion engine created faster and more flexible movement, directly raising the productivity of factory workers, housewives, truck drivers, and airline pilots as the machines they powered could rotate ever faster. Petroleum refining, chemicals, plastics, and pharmaceuticals all involve the physical rearrangement of molecules in ways that change materials into more productive forms. The complex of electric and electronic entertainment and information industries arrived in a void in which nothing comparable existed and had, one may safely conjecture, a greater impact on everyday life of the average family than the second and third generation developments witnessed more recently, e.g., VCRs, CDs, and large-screen color TVs, which provided merely better or more convenient ways of performing the same basic functions. A classic "second order" invention is the VCR, which combines the attributes of two first-order inventions, namely motion pictures and television, just as the contemporary cellular phone (part of the New Economy) is a second-order development of the telephone, a first-order invention. In fact, no current development in communications has achieved a change in communication speed comparable to the telegraph, which between 1840 and 1850 reduced elapsed time per word transmitted by a factor of three thousand (from 10 days to 5 minutes for a one-page message between New York and Chicago), and the cost by a factor of 100 (Sichel, 
Industrial Revolution, Page 26

p. 127). And does today's web access compare in excitement with the first live electronic contact with the outside world achieved as radio spread in the early 1920s and television in the late 1940s?

\section{The Declining Cost of Computer Power and the Pervasiveness of Diminishing Returns}

We now turn from history to an examination of the contemporary impact of computers and the internet. The analysis begins with a simple supply-demand analysis that relates shifting theoretical curves to the data on the prices and quantities of computer characteristics observed in the economy. We then turn to the role of diminishing returns implied by the rapid decline in the cost of computer power, to the attributes of the internet that have contributed to its rapid adoption by consumers and business firms, and finally to some of the factors that may have prevented computers and the internet from boosting MFP outside of durable manufacturing.

\section{The Declining Price of Computer Power}

The stunning difference between the computer and the Great Inventions of the past is the unprecedented rate of decline in the price of computer power. Since Gregory Chow's seminal paper (1967), computers have seemed the ideal application for the hedonic regression technique, in which the price of different computer models is explained by their characteristics (speed, memory, capacity of hard drive, presence and type of CD-ROM reader, and others) and by the passage of time. Since 
1986 the U. S. National Accounts have been based on a hedonic price index for computers and since 1996 on a system that combines this hedonic index with moving or "chain" weights to reflect the steady divergence of the computer price deflator from its value in any single base year. As shown in the top frame of Figure 4, the implicit price deflator for computer hardware, including peripherals, declined from 61,640 in 1961 to 36 at the end of 1999 (with a base $1996=100$ ), for an annual rate of decline of 19.4 percent per annum. There has been a corresponding increase in the quantity of computer attributes, and both the rate of price decline and quantity increase accelerated after 1995 (as indicated by the increasing spaces between the annual price and quantity observations starting in 1995).

While the rate of price change has varied over time, the notable feature of rapid price decline does not distinguish the New Economy from the 1950-80 interval dominated by the mainframe computer or the 1980-95 interval dominated by the transition from mainframe to PC applications prior to the invention of the Internet. ${ }^{42}$ Throughout its history, the economics of the computer has featured a steady downward shift in the supply curve of computer attributes at a rate much faster than the upward shift in the demand for computer services. In fact, the story is often told with a theoretical diagram like the bottom frame of Figure 4, in which the supply curve slides steadily downwards from $S_{1}$ to $S_{2}$ with no shift in the demand curve at all. ${ }^{43}$ Ignoring the possibility of a

42. Existing computer price deflators fail to take account of the radical decline in the price per calculation that occurred in the transition from mainframes to PCs (which have been studied only separately, not together). Gordon (1990, p. 239) calculates that the annual rate of price decline between 1972 and 1987 would have been 35 percent per annum rather than 20 percent per annum if this transitional benefit had been taken into account. This consideration further reduces the uniqueness of technological advance created by the New Economy.

43. Three examples of this graph applied to computers exhibiting no shift in the demand curve are (continued...) 
rightward shift in the demand curve from $D_{1}$ to $D_{2}$ (we return to this possibility below), the second distinguishing feature of the development of the computer industry is the unprecedented speed with which diminishing returns set in; while computer users steadily enjoy an increasing amount of consumer surplus as the price falls, the declining point of intersection of the supply curve with the fixed demand curve implies a rapid decline in the marginal utility or benefit of computer power.

\section{Declining Computer Cost Confronts the Fundamental Limitation of Time}

Since Gary Becker's seminal article (1965) on the economics of time, household production has been viewed as an activity which combines market goods and time. The fixed supply of time to any individual creates a fundamental limitation on the ability of exponential growth in computer speed and memory to create commensurate increases in output and productivity. In performing the two activities that were revolutionized by the personal computer, namely word processing and spreadsheets, I cannot type or think any faster than I did with my first 1983 personal computer that contained 1/100th of the memory and operated at 1/60th of the speed of my present model. The capital stock with which I work has increased by a factor of almost 30, according to the hedonic price methodology, yet my productivity has hardly budged, occasionally benefitting for a few seconds when I can jump from the beginning to the end of a 50-page paper much faster than in $1983 .{ }^{44}$ As a result,

43. (...continued)

Brynjolfsson (1996, p. 290), Gordon (1990, p. 46) and Sichel (1997, p. 17). The supply curves in this graph have been drawn as horizontal lines, both to simplify the subsequent discussion of consumer surplus and because there is no evidence of a rising marginal cost of producing additional computer speed, memory, and other characteristics at a given level of technology.

44. A price index that declines at 25 percent per year for 17 years reaches a level of 1.4 in 2000 on a base of (continued...) 
there has been an exponential rate of decline in my output-to-capital ratio, and an equally sharp decline in the marginal productivity of computer capital.

There is nothing unique about the applicability of diminishing returns to the computer hardware and software industries. Numerous industries have run into barriers to steady growth in productivity, most notably the airline industry when jet aircraft reached natural barriers of size and speed, and the electric utility industry when turbogenerator/boiler sets reached natural barriers of temperature and pressure. The apparent dearth of productivity growth in the construction and home maintenance industry reflects that electric portable power tools could only be invented once and have been subject to only marginal improvements in recent decades.

What makes diminishing returns particularly important in understanding the computer paradox is the sheer pace at which computer users are sliding down the computer demand curve to ever-lower marginal utility uses. One way of illustrating this point is to take word-processing. The upper frame in Figure 5 conjectures a total utility curve for word processing, plotted against the speed of the computer measured in $\mathrm{mHz}$. Plotted are successive improvements starting at point A with the memory typewriter, which eliminated much repetitive retyping. At point B comes the early slow DOS PC with Wordperfect 4.2. Much faster computer speeds allowed the development of Wordperfect 6.0 for DOS, with a fully graphical WYSIWYG interface, as at point C. Further orderof-magnitude increases in speed bring us today's state of the art at point $\mathrm{D}$, Windows 98 with the latest version of Microsoft Word. Yet look at how the curve flattens out. The real revolution in

44. (...continued)

1983 equals 100. This implies that my present $\$ 1000$ computer represents $\$ 70,100$ in 1983 prices, or 28 times the $\$ 2,500$ that I spent in 1983 on my first computer net of peripherals. 


\section{Industrial Revolution, Page 30}

word processing came at the beginning, by ending repetitive retyping and by allowing revisions to be inserted while the rest of the document would automatically reformat itself. The productivity enhancement of WYSIWYG was minor in comparison, and what was contributed by the final step to the latest version of Word for Windows, beyond the ease of training for novice users, escapes me. As the computer industry has developed, the steady decline in the prices of computer charcteristics has fueled the development of increasingly complex software with high requirements for speed and memory required by graphical point-and-click interfaces that yield increasingly small increments of true functionality. The race between hardware capability and software requirements has been aptly summed up in the phrase, "What Intel giveth, Microsoft taketh away."

The bottom frame of Figure 5 replots the same relationship with marginal utility on the vertical axis. This is the demand curve for computers which is drawn on the simplified assumption that word processing is the only use of computers, but the point can be made in multiple dimensions. As the diagram is drawn, a large part of the consumer surplus occurred in going from A to B to C, and further gains are relatively small. ${ }^{45}$

\section{Diminishing Returns and the David "Delay Hypothesis"}

The diminishing returns argument provides part of the answer to the Paul David (1990) "delay" hypothesis. The reason that electric light and electric motors took time to diffuse after their invention in the 1870 s is that initially they were very expensive and didn't work very well. But the

45. Even Business Week, normally enthusiastic about the benefits of the New Economy, admits that the latest increments in chip speed offer "a lot of speed you can't really use. . . a speedier chip won't mnake you type faster or think faster." See Wildstrom (1999, p. 23). 


\section{Industrial Revolution, Page 31}

mainframe and then personal computers worked reliably from the beginning, provided their main benefits early on, and encountered diminishing returns relatively soon. Personal computers are only a secondary step in the evolution of computer technology that began with the first commercial mainframe computer (the UNIVAC I in 1951). ${ }^{46}$ Many of the industries that are the heaviest users of computer technology, e.g., airlines, banks, and insurance companies, began in the 1960s and 1970s with mainframe technology and still perform the most computation-intensive activities on mainframes, often using PCs as smart terminals to access the mainframe data base. In this sense computers have been around for almost 50 years, not just a decade or so, and the "waiting for Godot" hypothesis of David and others loses further credibility.

\section{Why the Computers are not Everywhere}

One explanation of the Solow computer paradox (that "we can see the computer age everywhere except in the productivity statistics") is that the computers are not everywhere. The early work of Oliner and Sichel (1994) and Sichel (1997) emphasized the small share of computers in the capital stock, and the greater degree of optimism in their more recent work (Oliner and Sichel, 2000) results not from a sudden jump in the importance of computer spending - we saw in the bottom frame of Figure 2 that this did not happen - but rather in the accelerated rate of price decline and in an extension of their analysis to include not just computers but also semiconductors. Since the share of nominal spending on computers did not increase at all from 1987 to 1999, we can interpret

46. Many of us recall the 1957 Spencer Tracy and Katherine Hepburn movie The Desk Set, in which Hepburn's entire reference department was to be replaced by a computer named "Emerac". 


\section{Industrial Revolution, Page 32}

the rapid increase in computer speed and memory as a simple substitution in response to the declining price, and with a price elasticity of demand of minus unity there is no need to invoke an increase in the demand for computer attributes at all.

Some of the output of computers is, in principle, as productivity-enhancing as that of electric motors or motorized transport. From the earliest punch-card sorters in the 1890s, some applications of computer technology involved movement and speed. ${ }^{47}$ Numerically controlled machine tools, robots, and other computer-driven machinery has the same potential for productivity improvement as the earlier great inventions and doubtless accounts for the robust rate of productivity growth apparent in much of the durable manufacturing sector. The use of ever-faster computers and peripherals to churn out securities transactions, bank statements, and insurance policies has enhanced productivity growth in the finance/insurance sector. And, just as the motor car enormously increased personal mobility and flexibility, so the computer has spawned inventions whose main output is convenience, most notably the ATM machine.

Hand and Eye Coordination. Computers are less pervasive than is generally thought, however, because there are real limitations to the replacement of human beings by computers. Commercial aircraft, large and small alike, will always need two human pilots, no matter how advanced the avionics in the cockpit. Trucks will always need at least one driver. In manufacturing, some critical functions have proven to be resistant to automation, such as the connecting of tubes and

47. Sichel (p. 126) calculates that the cost per calculation of the Hollerith punch card machine declined by a factor of four between 1890 and 1900, the precursor of today's rapid declines in the ratio of price to performance. 
wires when an auto chassis is "married" to the body. ${ }^{48}$ No matter how powerful the computer hardware and how user-friendly the software, most functions provided by personal computers, including word-processing, spreadsheets, and data-base management, still require hands-on human contact through a keyboard and mouse to be productive.

Face-to-face Contact in the Services. By their nature, many services involve in-person contact between clients and practitioners, whether doctors, nurses, dentists, lawyers, professors, investment bankers, management consultants, bartenders, wait staff, bus boys, flight attendants, barbers, or beauticians. Many other services require in-person contact between an object and the practitioner, such as grocery cashiers, grocery baggers, parking lot attendants, valet parkers, auto repair, lawn maintenance, restaurant chefs, hotel housekeepers, and almost every type of maintenance of homes and machines. Computers are a relatively large share of capital in business, health, legal, and educational services, but in each of these the contribution of capital to productivity growth is relatively small.

\section{The Positive and Negative Side of the Internet}

The accelerated rate of price decline in computer attributes has been accompanied since 1995 by the invention of the Internet. ${ }^{49}$ In perhaps the most rapid diffusion of any invention since television

48. Ford engineers explained to a group of NBER economists (including this author) touring a plant in Lakewood, Ohio, on November 1, 1996, that the "marriage" would be the last operation in automobile assembly to be fully automated. In another tour with some of the same economists at the Toyota plant in Georgetown, Kentucky, on April 3, 1998, officials explained their aversion to automation and replacing humans with robots: "our philosophy is kaizan (continuous self-improvement), and machines cannot kaizan."

49. Here to simplify the presentation we will take the Internet as being synonomous with the World Wide Web 
Industrial Revolution, Page 34

in the late 1940s and early 1950s, by the end of the year 2000 the percentage of American households hooked up to the Internet will have reached 50 percent. ${ }^{50}$ Surely the invention of web browsers and the explosive growth of e-commerce rates as a major invention and should be interpreted as a rightward shift in the demand curve in the bottom frame of Figure 4 from $D_{1}$ to $D_{2}$. Such a rightward shift in the demand curve would imply an increase in consumer surplus associated with the lower supply curve $S_{2}$ from the triangle $J P_{2} B$ to the larger triangle $K P_{2} C$, in exactly the same way that supermarkets and superhighways raised the consumer surplus associated with the invention of the automobile (see footnote 36 above).

\section{The Apparent Absence of a Rightward Shift in Demand}

However, if there had been a discontinuous rightward shift in the demand curve for computer hardware due to the spread of the internet, we should have observed a noticeable flattening of the slope of the price-quantity relationship in the top frame of Figure 4, as the rate of increase of quantity accelerates relative to the rate of decline in price, but we do not. The rate of change of price and quantity both accelerate after 1995 (as indicated by the greater spacing between annual observations) but the slope does not change appreciably, suggesting that the spread of the internet is a byproduct of rapid technological change that is faster than in previous decades but not qualitatively different in

49. (...continued)

and the invention of web browsers, although the use of the Internet for e-mail, at least in the academic and scientific community, dates back at least to the early 1980s.

50. This projection is made by Henry Harteveldt, Senior Analyst at Forrester Research, in communications with the author. The misleading data of Cox and Alm (1999, Figure 8.1, p. 162) suggests that it took more than 25 years for television to reach 50 percent household penetration, but dating from the first commercial TV station in 1947 this penetration rate was reached in only seven years. See Kurian (1994), series R105 divided by A335. 


\section{Industrial Revolution, Page 35}

the relationship between supply and demand than earlier advances in the computer industry.

The data on the price and quantity of computer characteristics have previously been used to "map out" the demand curve (Brynjolfsson, 1996, p. 290). In fact, the slope of the price-quantity relationship was appreciably flatter during 1972-87 than during 1987-95 or 1995-99. If the demand curve has not shifted, the inverse of these slopes is the price elasticity of demand, namely $-1.96,-1.19$, and -1.11 in these three intervals, which can be compared with Brynjolfsson's (1996, p. 292) estimated price elasticity of

-1.33 over the period 1970-89. The apparent decline in the price elasticity is the counterpart of the fact that the nominal share of computer hardware expenditures in the total economy (which implicitly holds income constant) rose rapidly before 1987 but barely increased at all after that year, and this shift in the price-quantity slope is consistent with the view that the most important uses of computers were developed more than a decade into the past, not currently.

\section{Benefits of the Internet}

The "New Economy" was defined at the beginning of this paper as the apparent acceleration around 1995 in the rate of technical progress in IT, broadly conceived. However, most of the optimistic interpretations of this development point to the internet, or more specifically the invention of web browsers, as the central development that warrants calling the present era a new Industrial Revolution. Here we provide a brief summary of some of the main aspects of the internet treated as an industry and relate these aspects to our earlier decomposition of the post- 1995 productivity 
Industrial Revolution, Page 36

growth acceleration.

Barua et al. (1999) have proposed dividing the Internet Economy into four "layers:" (1) the internet infrastructure layer, (2) the internet applications layer, (3) the internet intermediary layer, and (4) the internet commerce layer. The first layer consists of hardware manufacturers, including IBM, Dell, HP, Cisco, Lucent, Sun, and many others, all included in either the computer hardware or telecommunications hardware industries. As we have seen above in Figure 3, this sector accounts for the largest single component of the post-1995 productivity growth acceleration, both the direct effect of faster MFP growth in computer hardware (including computer-related semiconductors) and the indirect capital-deepening effect of the investment boom in IT equipment. There is little debate about the dynamism of this sector, but rather about the uses to which this exponentially exploding quantity of computer power is being put.

The second layer consists of software, consulting, and training, and includes such companies as Microsoft and its competitors. The main debate concerning the productivity of this layer is whether the new BEA software deflators decline too slowly to capture the increased capability of the software being produced as part of this massive investment effort. ${ }^{51}$ However, as shown by Jorgenson and Stiroh (2000), substituting alternative software deflators with radically faster rates of price decline does not significantly change MFP in the rest of the economy; total output grows faster but this is

almost exactly cancelled out by faster growth in capital input. There is more capital deepening and

51. Producers' Durable Equipment investment in software in 1999 was $\$ 143.3$ billion, almost 50 percent larger than PDE in computer and peripheral hardware. 
a higher share of the productivity acceleration accounted for by the software industry, but no change in any conclusions about spillovers from software to the rest of the economy.

The third and fourth layers consist of providers of both intermediate goods and consumption goods. Many aggregators, portals, and content providers, e.g., Yahoo and Travelocity, sell information and services both to business firms and to consumers. To the extent that e-commerce is provided by one business to another, it is an intermediate good and not directly relevant for computing the productivity of final output in the non-computer economy. In this sense we do not need to debate whether business-to-business ("B2B") e-commerce is a fruitful invention. If the development of more efficient links in the supply chain reduces costs and allows the elimination of people and paper in the chain of intermediate transactions, then we should see the payoff in faster productivity growth in the non-computer economy. So far this payoff has appeared in other parts of durable manufacturing but not in rest of the economy. Thus our primary remaining question concerns the benefits of the Internet Economy in the provision of final goods.

The consumer benefits of the Internet are familiar. Perhaps the most important single consumer benefit, also now used universally within business firms, is e-mail. The use of the Internet for e-mail long predated the invention of web browsers, and the hardware and software requirements for straight e-mail, as opposed to e-commerce, are very small. The benefits of e-commerce include the provision of vast amounts of free information that was formerly expensive or inconvenient to obtain, including travel and sports schedules, hotel descriptions, maps, directions, news, security prices, and even entire encyclopedias. When items are purchased over the web rather than obtained for free, selection is often much better (especially for books, CDs and videos) than at traditional 
bricks and mortar stores, and prices are often lower, sometimes even when shipping costs are included. Auctions on sites like E-Bay provide a new mechanism that allows the flea market to spread from local communities and neighborhoods to a worldwide community of potential buyers and sellers. According to Smith, Bailey, and Brynjolfsson (1999), "early research suggests that electronic markets are more efficient than conventional markets with respect to price levels, menu costs, and price elasticity . . . although several studies find significant price dispersion in Internet markets."

If e-commerce contributes to holding down prices of goods traded in the non-computer part of the economy, then this will provide an additional factor holding down inflation in addition to the direct impact of the falling prices of computer hardware discussed earlier. However, the low prices of many consumer web vendors have resulted in unsustainable financial losses financed temporarily but surely not permanently by venture capitalists and stockholders. It remains to be seen how much the web reduces consumer prices once stockholders begin to require that e-commerce vendors actually earn profits (see Byron, 2000). ${ }^{52}$

\section{Qualifying the Internet Benefit: Numbers of Products and a Fixed Time Endowment}

The enormous variety of products and services available on the internet, both for free and for pay, might seem to be an invention worthy of comparison with the Great Inventions of the past. Yet the mere fact that new products and services are being developed is not sufficient for an Industrial Revolution, which requires that the rate of improvement must be greater than in the past. In Triplett's

52. Bulkeley and Carlton (2000, p. A4) report the following ratios of net profits to 1999 sales: Amazon.com -43.9, buy.com -21.8, eToys -110.3, and drugstore.com -331.8. 
insightful critique (1999, pp. 326-27), the enthusiastic retelling of anecdotes about the New Economy ignores the distinction between arithmetic numbers and logarithmic growth rates. If an economy has 10 products and invents a new one, the growth rate is 10 percent. If many years later the economy has 100 products, it must invent 10 new ones to grow at the same rate and invent 12 or 13 to register a significant increase in the growth rate. Today's U. S. real GDP is more than 40 times greater than in 1880, but does anyone think that today we are inventing 40 times as many products as in a single decade that yielded the invention of electricity, the telephone, motion pictures, the phonograph, the indoor toilet, and the many others discussed above?

Skepticism of the importance of the Internet viewed as an invention need to distinguish between consumer welfare and productivity. For consumers the new combination of home PCs and web access provides a valuable invention, for otherwise why would internet access reach a 50 percent household penetration rate only six years after the invention of web browsers? But here again, as for computers in general, the vast new variety of Internet products collides with the same fixed quantity of time available to each household member. Thus much internet use represents a substitution from other forms of entertainment. Internet games replace hand-held games. Downloaded internet music replaces purchased CDs. Internet pornography replaces purchased or rented adult videos. Other forms of internet entertainment and surfing for information replace hours previously spent watching television or reading books. New evidence of diminishing returns is now emerging: use of PCs and of the Internet is declining among newer purchasers who paid less for their machines and appear to value them less: "new purchasers who paid less than $\$ 1,000$ for their machines are less involved with them," and apparently only two-thirds of computer owners who subscribe to Internet services actually 
Industrial Revolution, Page 40

use them (Clark, 1999). As Herbert Simon once said "A wealth of information creates a poverty of attention"..$^{53}$

\section{Why Isn't the Internet More Productive?}

Finally, we come to the essential question raised by our previous productivity decomposition: why has not the New Economy in general and the Internet in particular boosted MFP growth outside of the durable manufacturing sector? What explains the apparent contradiction between this unimpressive productivity performance and the eagerness with which millions of business firms and consumers have purchased business and home computers, as well as internet infrastructure, spawning whole new industries and creating vast wealth? This conflict is highlighted by findings in microeconomic cross-section studies that computers raise productivity at the level of individual firms. For instance, Brynjolfsson and Hitt (1996) estimate that the gross rate of return on investment in computers exceeds 50 percent annually, compared to 15 to 20 percent for other investments in the sample of firms that they analyzed.

At least four factors may play a role in resolving the conflict: market-share protection, recreation of old activities rather than creation of new activities, duplicative activity, and consumption on the job. The need to protect market share against competitors explains much of the investment and maintenance expense of web sites. Barnes and Noble and Borders would have been content to play a dominant role in the retailing of books but were forced by competition from Amazon to become "clicks and mortar" organizations by developing their own web sites that duplicated much

53. This quote was related to me by Hal Varian. 


\section{Industrial Revolution, Page 41}

of their previous retail activity and most of what Amazon had already pioneered. More generally, computers are used extensively to provide information aimed at taking customers, profits, or capital gains away from other companies. This is a zero-sum game involving redistribution of wealth rather than the increase of wealth, yet each individual firm has a strong incentive to make computer investments that, if they do not snatch wealth away from someone else, at least act as a defensive blockade against a hostile attack. This may be at the heart of the apparent contradiction between the Brynjolffson-Hitt micro evidence and the failure of computers to spark a productivity growth revival outside of durable manufacturing; the high payoff to computers for individual firms may reflect redistributions to computer-using firms from firms that use computers less intensively. There is a "keeping up with the Joneses" aspect of hardware and software purchase motivated by competition, employee satisfaction, and employee recruitment. ${ }^{54}$

Second, much internet content is not truly new, but rather consists of preexisting forms of information now made available more cheaply and conveniently, in contrast to the sense in which the Great Inventions created truly new products and activities. Internet surfing of airline schedules provides a lower cost, although not necessarily faster, alternative method of obtaining information already available in airline timetables, from the printed Official Airline Guide, and from the neighborhood travel agent. Obtaining stock quotes and performing trades on the web does not represent the invention of a new activity but rather a reduction in cost of performing an old activity.

54. There seems to be a deeper contradiction between the macro and micro evidence that has not yet been resolved. For instance, in a study of MFP growth and computer capital across a number of industries, Stiroh (1998) finds that "For all computer-using sectors ... the average growth rate of multifactor producitivity fell while [computer] capital grew." 


\section{Industrial Revolution, Page 42}

A third factor subtracting from productivity is the duplicative aspect of the Internet. Much e-commerce is an alternative to mail-order catalog shopping (another invention of the $1870 \mathrm{~s}$ ). ${ }^{55}$ Just as Wanamaker's and Macy's department stores began to issue catalogs to supplement their existing retail operations in the early 1870 s, so Land's End, Spiegel's, and many other catalog operators have supplemented their existing operations with web sites in the late 1990s. Yet the catalogs have not disappeared; the full cost of printing and mailing the catalogs is still incurred, but on top of that must be expended many millions on developing and maintaining duplicative web sites. While it is cheaper to take an order from a web customer than with a human worker answering a phone, much of the rest of the transaction involves the same physical input of labor in building and stocking warehouses, selecting items from warehouse shelves, packing them, and shipping them. The brown UPS trucks are thriving with e-commerce, but each truck still requires one driver. Far from reducing or eliminating the use of paper, in the electronic age "For getting attention in a professional way, paper still matters. Nobody even asks anymore if paper is going away." ${ }^{156} \quad$ An example closer to home is the added cost to academic societies of developing web sites to provide information already available in their printed journals. The Econometric Society now provides duplicate announcements of most of its activities through the back pages of its journal and through its web site, which costs money to develop and maintain, and it like other societies is under increasing pressure to provide the contents of its journal and even papers given at its regional meetings for free to its members on the

55. The history of mail-order catalogs is summarized in Gordon (1990), pp. 419-23.

56. The speaker is the president of NowDocs.com, as quoted by Doan (2000, p. 140). On the growth in paper usage, see also "Bad News for Trees," Economist, December 19, 1998, pp. 123-6. 


\section{Industrial Revolution, Page 43}

web. Costs increase and membership erodes as information becomes available for free. Economists gain a consumer surplus in having more convenient access to research, but convenience for professors is not a final good. The final product, education and research, is affected little if at all by the ease of access of references. ${ }^{57}$

Finally, productivity on the job may be impaired by the growing use of business computers with continuous fast web access for consumption purposes. A research service finds that people spend more than twice as much time online at the office as they do at home, and that web users at the office take advantage of high-speed connections to access entertainment sites more frequently at work than at home. In fact the most-visited site from the office is eBay, and three financial trading sites are not far behind (Farrell, 2000, p. A1). Traffic on many consumer-oriented web sites peaks not at night, when people are at home, but in the middle of the day, when they are at work. ${ }^{58}$ The media have gleefully reported that a large fraction of on-line equity trading is happening at the office, not at home.$^{59}$ Employers are so disturbed by the contining use of office computers for personal e-mail that the number of companies using "surveillance software" to monitor their employees' e-mail usage is "soaring" (Guernsey, 2000, p. C1). While it may be unusual to include a cartoon in an academic

57. In a related investigation of the payoff for academic research of information technology, Hamermesh and Oster (1997) find that articles with co-authors working at long distance from each other actually have fewer citations than other articles; "a greater ease of overcoming distance does not enhance productivity" (p. 18). They interpret the rise in long-distance co-authorship as mainly a consumption good as academic friends find it easier to work together.

58. "Online-shopping traffice doesn't surge in the dead of night but in the middle of the workday, experts say. Active Research Inc., a San Francisco Web-based market-research company, says retail clicks begin to gain steam around 9 a.m. and spike around lunchtime. Gamedealer.com, an Internet games site, says 65\% of its orders are placed during the weak from 9 a.m. to 5 p.m" (De Lisser, 1999).

59. See, for instance, Bennett (2000). See also "Workers Leaving Water Cooler for Internet," New York Times, May 20, 1999, p. A1. 
paper, Figure 6 is a perfect way to close this section.

\section{A Possible Qualification: Mismeasurement}

A possible resolution to the Solow paradox, which remains intact outside of durable manufacturing, is that many of the benefits of computers have been mismeasured. PCs and the Internet have doubtless created consumer surplus, but so did most of the Great Inventions of the past. Several thought experiments provide convincing evidence. For instance, we might gather together a group of Houston residents and ask them "if you could choose only one of the following two inventions, air conditioning or the Internet, which would you choose?" A parallel question might be asked in Minneapolis, "if you could choose only one of the following two inventions, indoor plumbing or the Internet, which would you choose?"

In addition to the likelihood that even larger amounts of consumer surplus were missed in the past, another overriding factor limits the importance of the measurement issue. The heaviest uses of computers are in industries that provide mainly or entirely intermediate goods, especially wholesale trade, finance, many parts of the insurance industry, business services, and legal services. If computers truly raised the output of these intermediate industries in unmeasured ways, then the benefits should show up in the output of final goods industries that exhibit higher output in relation to their undermeasured inputs. Yet this spillover from intermediate to final goods industries is just what cannot be found in the official data on output and productivity growth, at least outside of the durable manufacturing sector. 
Industrial Revolution, Page 45

\section{Conclusion}

This paper reaches the paradoxical conclusion that the "New Economy," defined as the post1995 acceleration in the rate of technical change in information technology, together with the development of the Internet, has been both a great success and a profound disappointment. The resolution of this paradox is that the New Economy has created a dynamic explosion of productivity growth in the durable manufacturing sector, both in the manufacturing of computers and semiconductors and of other types of durables. Beyond normal cyclical effects and some minor factors, all of the acceleration in the growth rate of labor productivity after 1995 in the aggregate economy can be traced to the New Economy operating through three channels, an acceleration in multi-factor productivity (MFP) growth in computers themselves, an investment boom which has caused an acceleration of capital deepening attributable entirely to computers and semiconductors (with no contribution from other types of capital), and an acceleration in MFP growth in the rest of durable manufacturing — including New Economy industries like telecommunications. This productivity explosion has boosted the economy's overall rate of productivity growth, reduced the inflation rate, created enormous wealth in the stock market, and allowed the Fed to postpone the tightening of monetary policy in the face of a steadily declining unemployment rate.

However, the remaining part of the paradox is what concerns us. Our decomposition of productivity growth leaves less than nothing left over for the 88 percent of the economy outside of durable manufacturing; trend MFP growth there has actually decelerated. Not only has there been no spillover from the New Economy in the form of a structural acceleration in MFP growth in the rest 


\section{Industrial Revolution, Page 46}

of the economy, but there has not even been an acceleration in trend labor productivity growth in response to a massive investment boom in computers and related equipment. Outside of durable manufacturing, the New Economy has been remarkably unfruitful as a creator of productivity growth.

Part of our conclusion is based on an analysis which divides the post-1995 acceleration in productivity growth between a permanent trend effect and a temporary cyclical effect, building on a previous literature showing that productivity grows more rapidly than trend when output grows faster than trend. Since even the most optimistic advocates of a New Economy revolution deny that the ebullient rates of output growth in 1998 and especially 1999 were sustainable, some fraction of the productivity revival must be temporary. In developing the trend-cycle split, we had to interpret the decline in the actual unemployment rate that had allowed output to grow so rapidly during 199599. Of the decline in the unemployment rate from 5.6 percent in 1995 to 4.2 percent in 1999, we assumed that 0.6 points of the decline were sustainable and 0.8 were not. An alternative assumption that 1.1 points were sustainable and 0.4 points were not would shift 0.11 percentage points of annual productivity growth from the cyclical to trend category and modify our conclusions modestly but would not change our most surprising conclusion, that trend MFP growth outside of durable manufacturing has actually slowed since 1995 .

In assessing the importance of the New Economy and particularly the Internet as an invention, we have applied a tough test. To measure up, the New Economy had to equal the combined impact of five clusters of Great Inventions that originated in the period 1860-1900 and together constitute what is sometimes called the "Second Industrial Revolution." In one sense the question answers itself by simply listing the honor roll of Great Inventions, some of which were electric light, the electric 
motor, the automobile, motor transport, air transport, the modern chemical industry, the telephone, the motion picture, radio, television, and last but not least, the indoor toilet. Even derivatives of electricity like the air conditioner are probably more valued by the consumer, at least in the southern half of the United States, than the invention of the Internet, and of course the computer and the Internet were in this sense subsidiary inventions that required the prior invention of electricity.

The fundamental economics of the computer in general and the Internet in particular establish a conflict between rapid exponential growth in computer speed and memory on the one hand, and the fixed endowment of human time on the other. As a result most of the initial applications of the mainframe and personal computers have encountered the rapid onset of diminishing returns, and much of the use of the Internet represents a substitution from one type of entertainment or informationgathering to another. Internet surfing may be fun, but it represents a far smaller increment in the standard of living than achieved by the extension of day into night achieved by electric light, the revolution in factory efficiency achieved by the electric motor, the flexibility and freedom achieved by the automobile, the saving of time and shrinking of the globe achieved by the airplane, the new materials achieved by the chemical industry, the first sense of live two-way communication achieved by the telephone, the arrival of live news and entertainment into the family parlor achieved by radio and then television, and the enormous improvements in life expectancy, health, and comfort achieved by urban sanitation and indoor plumbing. 
Industrial Revolution, Page 48

\section{REFERENCES}

Barua, Anitesh, Jon Pennell, Jay Shutter, and Andrew B. Whinston. 1999. "Measuring the Internet Economy: An Exploratory Study." Working paper, June 10. Updated versions available at http://crec.bus.utexas.edu.

Basu, Susanto. 1996. "Procyclical Productivity: Increasing Returns or Cyclical Utilization?" Quarterly Journal of Economics, 111:4, pp. 719-51.

Becker, Gary S. 1965). "A Theory of the Allocation of Time," Economic Journal, 75:3, pp. 493-517.

Bennett, Johanna. 2000. "Placing Stock Trades While at the Office Adds a Little Risk," Wall Street Journal, March 15, p. B10D.

Bettmann, Otto L. 1974. The Good Old Days - They Were Terrible! New York: Random House.

Bresnahan, Timothy F., and Robert J. Gordon, eds. 1997. The Economic of New Goods. Chicago: University of Chicago Press for NBER.

Brynjolfsson, Erik. 1996. "The Contribution of Information Technology to Consumer Welfare," Information Systems Research, 7:3, September, pp. 281-300.

Brynjolfsson, Erik, and Lorin M. Hitt. 1996. "Paradox Lost? Firm-level Evidence on the Returns to Information Systems Spending", Management Science, April.

Brynjolfsson, Erik, Lorin M. Hitt, and Shinkyu Yang. 2000. "Intangible Assets: How the Interaction of Computers and Organizational Structure Affects Stock Market Valuations," presented at AEA meetings, Boston, January.

Bulkeley, William M., and Jim Carlton. 2000. "E-Tail Gets Derailed, How Web Upstarts Misjudged the Game," Wall Street Journal, April 5, pp. A1, A4,

Bunch, Bryan, and Alexander Hellemans. 1993. The Timetables of Technology: A Chronology of the Most Important People and Events in the History of Technology. New York: Touchstone.

Byron, Christopher. 2000. "Balance Due: In the hunt for elusive profits, consumer Web sites will be the first casualties," Fortune, February 21, pp. 104-8. 
Checkland, S. G. 1987. "Industrial Revolution," in The New Palgrave: A Dictionary of Economics. John Eatwell, Murray Milgate, and Peter Newman, eds. London: Macmillan, pp. 81115.

Clark, Don. 1999. "Survey Finds PC Usage in Homes Has Dropped," Wall Street Journal, June 21, p. B7.

Cortada, James W. 1993. Before the Computer: IBM, NCR, Burroughs, and Remeington Rand and the Industry They Created, 1865-1956. Princeton: Princeton University Press.

David, Paul A. 1990. "The Dynamo and the Computer: An Historical Perspective on the Modern Productivity Paradox," American Economic Review (Papers and Proceedings), 80:2, pp. $355-61$.

de Lisser, Eleena. 1999. "One-Click Commerce: What People Do Now To Goof Off at Work," Wall Street Journal, September 24, p. A1.

Denison, Edward F. 1962. The Sources of Economic Growth in the United States and the Alternatives Before Us. New York: Committee for Economic Development, Supplementary Paper no. 13.

Doan, Amy. 2000. "Paper Boy," Forbes, February 21, p. 140.

Dudley, Leonard. 1999. "Communications and Economic Growth," European Economic Review, 43, pp. 595-619.

Farrell, Greg. 2000. "Online time soars at office; Not all surfing work-related," USA Today, February 18, p. A1.

Flamm, Kenneth. 1997. More for Less: The Economic Impact of Semiconductors. Washington: Semiconductor Industry Association, December.

Gordon, Robert J. 1990. The Measurement of Durable Goods Prices. Chicago: University of Chicago Press for NBER.

Gordon, Robert J. 1993. "The Jobless Recovery: Does It Signal a New Era of ProductivityLed Growth?" Brookings Papers on Economic Activity, 24:1, pp. 271-316.

Gordon, Robert J. 1997. "The Time-Varying NAIRU and its Implications for Economic Policy," Journal of Economic Perspectives, Winter, 11:1, pp. 11-32. 
Gordon, Robert J. 1998. "Foundations of the Goldilocks Economy: Supply Shocks and the Time-Varying NAIRU," Brookings Papers on Economic Activity, 29:2, pp. 297-333.

Gordon, Robert J. 1999. "U. S. Economic Growth Since 1870: One Big Wave?" American Economic Review (Papers and Proceedings), 89:2, pp. 123-8.

Gordon, Robert J. 2000a. Macroeconomics, eighth edition. Reading MA: Addison-Wesley.

Gordon, Robert J. 2000b. "Interpreting the 'One Big Wave' in U. S. Long-term Productivity Growth," in Productivity, Technology, and Economic Growth. Bart van Ark, Simon Kuipers, and Gerard Kuper, eds. Amsterdam: Kluwer Publishers, forthcoming.

Gordon, Robert J. 2000c. "Has the New Economy Rendered the Productivity Slowdown Obsolete?" Unpublished working paper, Northwestern University, April.

Griliches, Zvi. 1960. "Measuring Inputs in Agriculture: A Critical Survey," Journal of Farm Economics, 42:5, pp. 1411-33.

Guernsey, Lisa. 2000. "You've Got Inappropriate Mail: Monitoring of Office E-mail is Increasing," New York Times, April 5, pp. C1, C10.

Hamermesh, Daniel S. and Sharon M. Oster. 1997. "Tools or Toys? The Impact of High Technology on Scholarly Productivity." Manuscript, November.

Hultgren Thor. 1960. "Changes in Labor Cost during Cycles in Production and Business." Occasional Paper 74. New York: National Bureau of Economic Research.

Ip, Greg. 2000. "Market on a High Wire," Wall Street Journal, January 18, p. C1.

Jorgenson, Dale W. and Zvi Griliches. 1967. "The Explanation of Productivity Change," Review of Economic Studies, 34:3, pp. 249-83.

Jorgenson, Dale W. and Kevin J. Stiroh. 2000. "Raising the Speed Limit: U. S. Economic Growth in the Information Age," Brookings Papers on Economic Activity, 31:1, forthcoming.

Katz, Lawrence F., and Alan B. Krueger. 1999. "The High-Pressure U. S. Labor Market of the 1990s," Brookings Papers on Economic Activity, 30:1, pp. 1-65.

Kurian, George Thomas. 1994. Datapedia of the United States, 1790-2000. Lanham MD: Bernan Press. 


\section{Industrial Revolution, Page 51}

McGuckin, Robert H. and Kevin J. Stiroh. 1998. "Computers Can Accelerate Productivity Growth," Issues in Science and Technology, Summer, pp. 41-48.

Mokyr, Joel. 1997. "Are We Living in the Middle of an Industrial Revolution?" Federal Reserve Bank of Kansas City Economic Review, Second Quarter, pp. 31-43.

Mokyr, Joel and Rebecca Stein. 1997. "Science, Health, and Household Technology: The Effect of the Pasteur Revolution on Consumer Demand." In Bresnahan and Gordon (1997), pp. 143200.

Nordhaus, William D. (1997). "Do Real-Output and Real-Wage Measures Capture Reality? The History of Lighting Suggests Not." In Bresnahan and Gordon (1997), pp. 29-66.

Nordhaus, William D. 1999. "The Health of Nations: The Contribution of Improved Health to Living Standards," working paper, Yale University, December 17.

Oi, Walter Y. 1962. "Labor as a Quasi-Fixed Factor," Journal of Political Economy, 70:4, December, pp. 538-55.

Oi, Walter Y. 1997. "The Welfare Implications of Invention," in Bresnahan and Gordon, eds. (1997), pp. 109-41.

Okun, Arthur M. 1962. "The Gap between Actual and Potential Output," Proceedings of the American Statistical Association, reprinted in Edmund S. Phelps, ed., Problems of the Modern Economy. New York: Norton, 1965.

Oliner, Stephen D., and Daniel E. Sichel. 2000. "The Resurgence of Growth in the Late 1990s: Is Information Technology the Story?" working paper, Federal Reserve Board, February.

Jacob M. Schlesinger and Yochi J. Dreazen. 2000. "Inflation Shows SIgns of Stirring as Forces Restraining it Wane," Wall Street Journal, April 17, p. A1.

Sichel, Daniel E. 1997. The Computer Revolution: An Economic Perspective. Washington: Brookings.

Smith, Michael D., Joseph Bailey, and Erik Brynjolfsson. 1999. "Understanding Digital Markets: Review and Assessment." In Erik Brynjolfsson and Brian Kahin, eds. Understanding the Digital Economy. Cambridge: MIT Press.

Staiger, Douglas, James H. Stock, and Mark W. Watson, Mark W. 1997. "The NAIRU, 
Unemployment, and Monetary Policy," Journal of Economic Perspectives, Winter, 11, pp. 33-49.

Stiroh, Kevin J. 1998. "Computers, Productivity and Input Substitution," Economic Inquiry, 36:2, April, pp. 175-91.7

Triplett, Jack E. 1999. "The Solow Computer Paradox: What do Computers do to Productivity?" Candian Journal of Economics, 32:2, April, pp. 309-34.

Uchitelle, Louis. 2000. "Economic View: Productivity Finally Shows the Impact of Computers," New York Times, March 12, section 3, p. 4.

Wildstrom, Stephen H. 1999. "Pentium III: Enough Already?" Business Week, March 22, p. 23. 
Industrial Revolution, Page 53

\section{DATA APPENDIX}

\section{Sources for Table 1.}

1870-1995. Lines 1-6 from Gordon (2000b), Table 1. Lines 7-11 from Gordon (2000b), Table 6.

1995-1999. All data are taken from Oliner and Sichel (2000) and are transformed as follows. Output (line 1): Table 1, line 1.

Labor hours (line 2): Table 1, line 7, divided by 0.67 , the implicit share of labor.

Capital (line 3): Composition-adjusted capital (see below for source of line 7) minus 0.71, which is the difference between the growth of capital services and capital stock in Jorgenson and Stiroh (2000, Tables 1 and 2, column 1).

MFP (line 6): Output growth minus input growth, using weights of 0.67 and 0.33 on labor and capital, respectively.

Labor hours (line 7): Table 1 , line 7 plus line 8 , divided by 0.67 , the implicit share of labor.

Capital (line 8): Table 1, line 2 plus line 6 , divided by 0.33 , the implicit share of capital.

MFP (line 11): Table 2, line 9.

\section{Sources for Table 2.}

Actual and trend growth and contribution of price measurement (lines 1-6): Gordon (2000c), Tables 1 and 2.

Lines 6, 9, and 10 are from Oliner-Sichel (2000), in each case comparing their growth rates for 1995-99 with a weighted average of 1973-90 and 1990-95. The table and line sources from Oliner-Sichel are as follows:

Labor quality (line 7): Table 2, line 8. 
Capital deepening (line 9): Table 2, line 2.

MFP growth in computers and computer-related semi-conductors (line 10): Table 4, line 5. Comparing Table 4, lines 2 and 5, of the total effect of $0.29,0.10$ is due to computers (and hence is omitted from column 2 in our Table 2) and the remaining 0.19 is due to computer-related semiconductor manufacture. 
Table 1

Growth Rates of Output, Inputs, and Multifactor Productivity, Selected Intervals, 1870-1999

\begin{tabular}{||lcccc||}
\hline \multicolumn{1}{|l}{} & $\mathbf{1 8 7 0 - 1 9 1 3}$ & $\mathbf{1 9 1 3 - 1 9 7 2}$ & $\mathbf{1 9 7 2 - 1 9 9 5}$ & $\mathbf{1 9 9 5 - 1 9 9 9}$ \\
\hline 1. Output $(y)$ & 4.42 & 3.14 & 2.75 & 4.90 \\
\hline Without Composition Adjustment & & & & \\
2. Labor Hours $(h)$ & 3.24 & 1.28 & 1.71 & 2.25 \\
3. Capital $(k)$ & 4.16 & 2.07 & 2.98 & 4.87 \\
4. Capital per Hour $(k-h)$ & 0.92 & 0.79 & 1.27 & 2.62 \\
5. Output per Hour $(y-h)$ & 1.18 & 1.86 & 1.04 & 2.65 \\
6. MFP $(m)$ & 0.77 & 1.60 & 0.62 & 1.79 \\
\hline With Composition Adjustment & & & & \\
7. Labor Hours $(h)$ & 3.73 & 1.72 & 2.09 & 2.71 \\
8. Capital $(k)$ & 4.22 & 2.76 & 4.04 & 5.58 \\
9. Capital per hour $(k-h)$ & 0.49 & 1.04 & 1.95 & 2.87 \\
10. Output per Hour $(y-n)$ & 0.69 & 1.42 & 0.66 & 2.19 \\
11. MFP $(m)$ & 0.47 & 1.08 & 0.02 & 1.25 \\
\hline \hline
\end{tabular}

Sources: $\quad$ See data appendix. 


\section{Table 2}

Decomposition of Growth in Output Per Hour, 1995:4-1999:4,

Into Contributions of Cyclical Effects and

Structual Change in Trend Growth

(Percentage Growth Rates at Annual Rate)

\begin{tabular}{|c|c|c|c|}
\hline & $\begin{array}{c}\text { Nonfarm Private } \\
\text { Business }\end{array}$ & $\begin{array}{c}\text { NFPB } \\
\text { Excluding } \\
\text { Computer } \\
\text { Hardware } \\
\text { Manufacturing }\end{array}$ & $\begin{array}{c}\text { NFPB } \\
\text { Excluding } \\
\text { Durable } \\
\text { Manufacturing }\end{array}$ \\
\hline 1. Actual Growth & 2.82 & 2.42 & 2.05 \\
\hline 2. Contribution of Cyclical Effect & 0.54 & 0.55 & 0.62 \\
\hline 3. Growth in Trend (line 1 - line 2) & 2.28 & 1.87 & 1.43 \\
\hline 4. Trend, 1972:2 - 1995:4 & 1.47 & 1.25 & 1.19 \\
\hline 5. Acceleration of Trend (line 3 - line 4) & 0.81 & 0.62 & 0.24 \\
\hline $\begin{array}{l}\text { 6. Contribution of Price } \\
\text { Measurement }\end{array}$ & 0.14 & 0.14 & 0.14 \\
\hline 7. Contribution of Labor Quality & 0.05 & 0.05 & 0.05 \\
\hline $\begin{array}{l}\text { 8. Structural Acceleration } \\
\text { in Labor Productivity (line } 5 \text { - line 6) }\end{array}$ & 0.62 & 0.43 & 0.05 \\
\hline 9. Contribution of Capital Deepening & 0.33 & 0.33 & 0.33 \\
\hline $\begin{array}{l}\text { 10. Contribution of MFP Growth in } \\
\text { Computer and Computer-Related } \\
\text { Semiconductor Manufacturing }\end{array}$ & 0.29 & 0.19 &.--- \\
\hline $\begin{array}{l}\text { 11. Structural Acceleration in MFP } \\
\text { (line } 7 \text { - lines } 8 \text { through 10) }\end{array}$ & 0.00 & -0.09 & -0.28 \\
\hline
\end{tabular}

Sources: $\quad$ See data appendix. 


\section{Table 3}

Greatest Engineering Achievements of the Twentieth Century

\begin{tabular}{||ll||}
\hline 1. Electrification (Cluster 1) & 11. Highways (Cluster 2) \\
2. Automobile (Cluster 2) & 12. Spacecraft \\
3. Airplane (Cluster 2) & 13. The Internet \\
4. Water Supply and Distribution & 14. Imaging \\
$\quad$ Cluster 5) & 15. Household Appliances (Cluster 1) \\
5. Electronics & 16. Health Technologies \\
6. Radio and Television (Cluster 4) & 17. Petroleum and Petrochemical \\
7. Agricultural Mechanization (Cluster 2) & \multicolumn{1}{c}{ Technologies (Cluster 3) } \\
8. Computers & 18. Laser and Fiber Optics \\
9. Telephone (Cluster 4) & 19. Nuclear Technologies \\
10. Air Conditioning and & 20. High-performance Materials \\
\hline
\end{tabular}

Source: $\quad$ www.greatachievements.org

Note: References to "Cluster" refer to the groupings of the five "Great Inventions" in the text. 

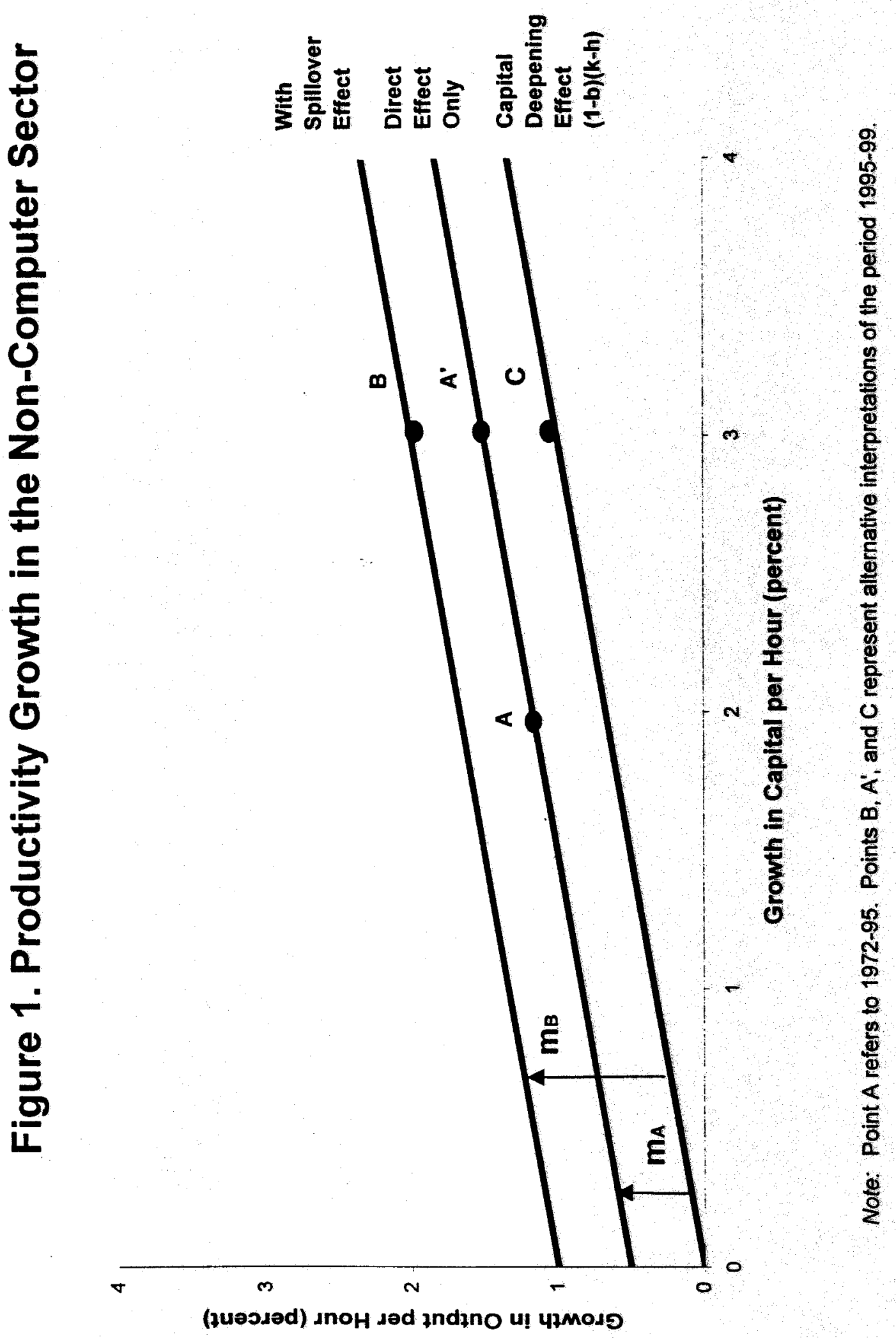
Figure 2. Final Sales of Computers and Peripherals, Fourquarter rate of Price Change and Nominal Share in

Nonfarm Nonhousing Business GDP, 1987-99
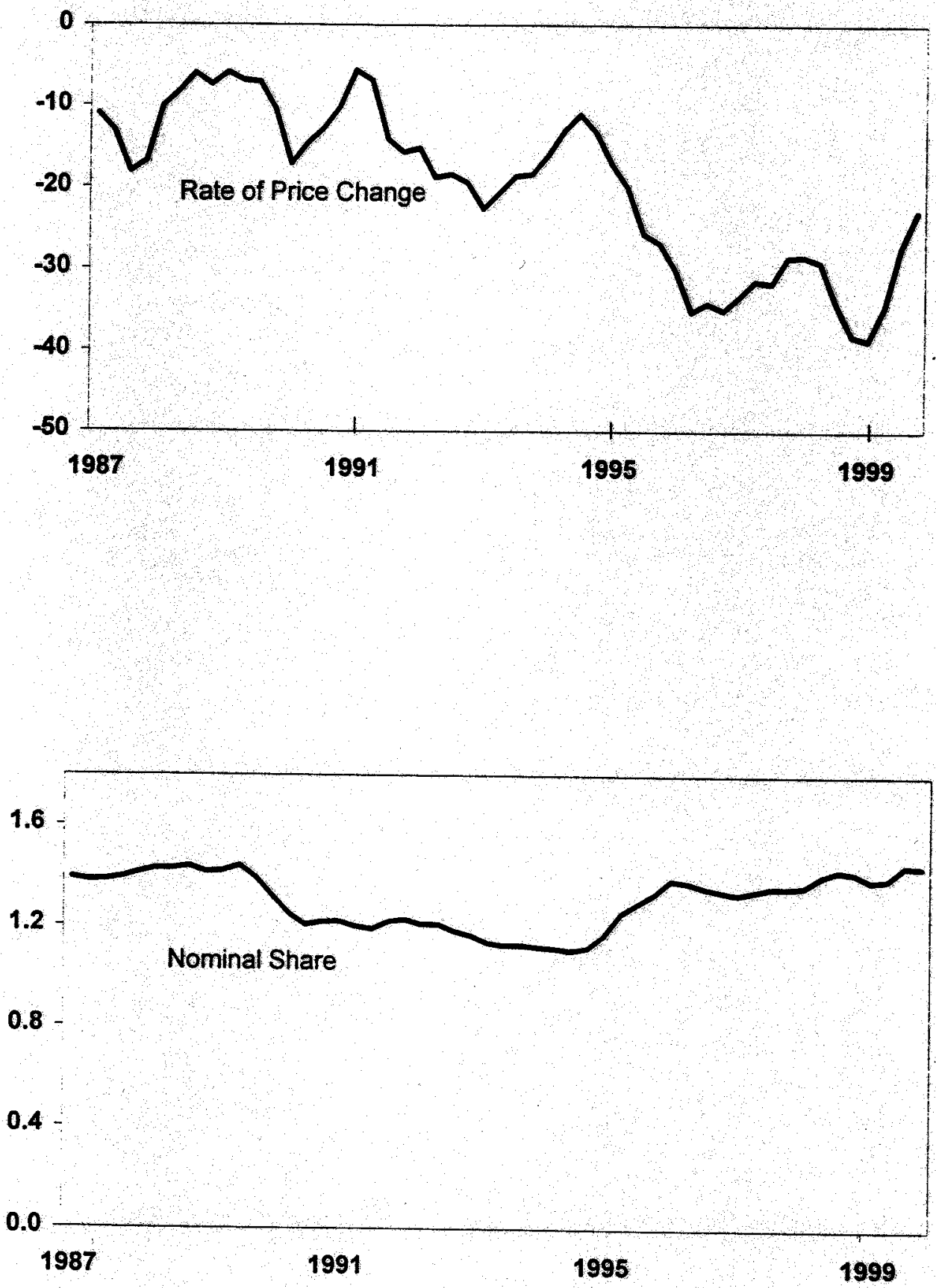


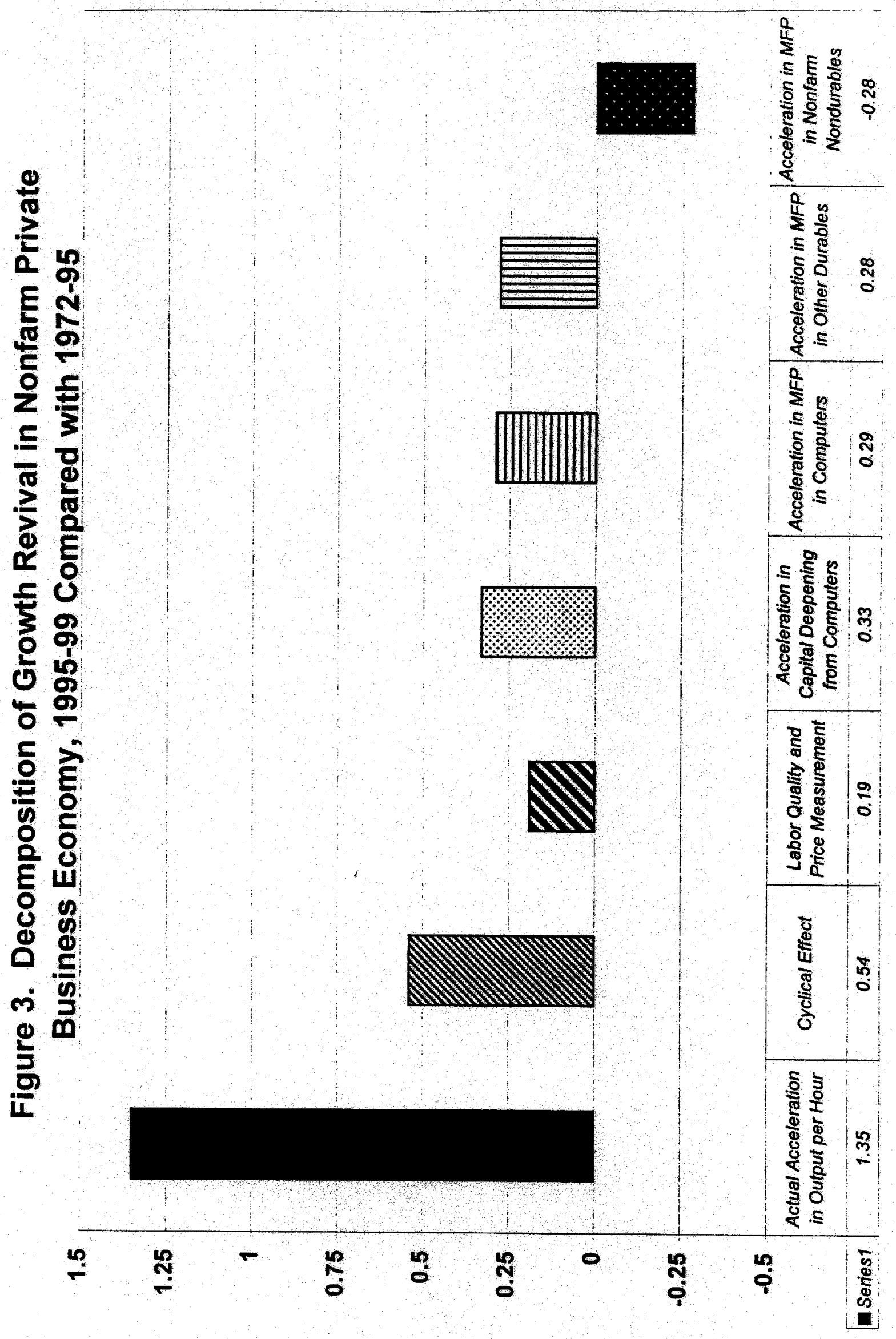


Figure 4. The Price and Quantity of Computer

Characteristics
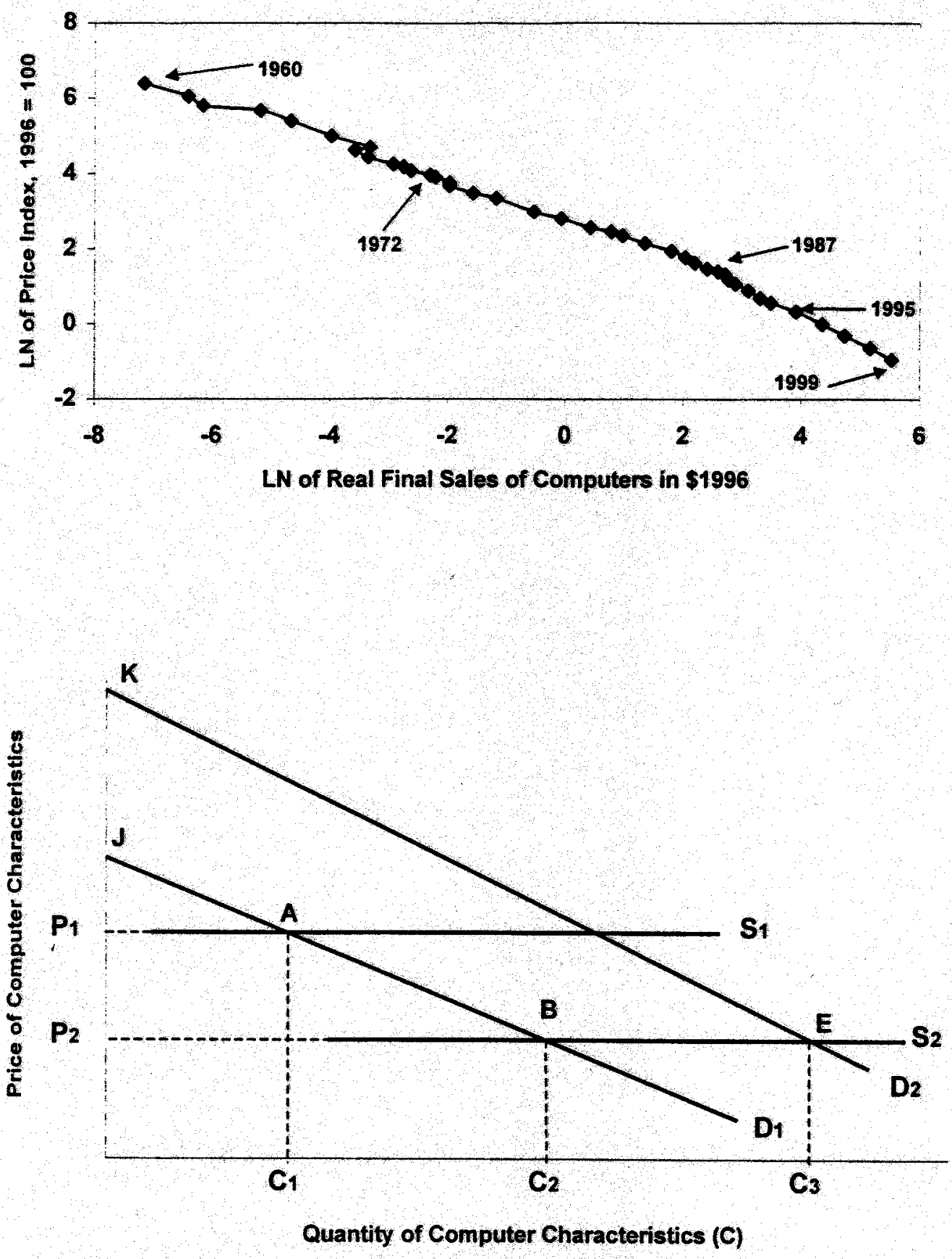

Source: Nominal final sales of computers and peripherals from BEA, linked to Producers' Durable Equipment for computers prior to 1987. Implicit Deflator from BEA back to 1972, for 1960-72 from Gordon (1990), Table 6.10, p. 226 
Figure 5

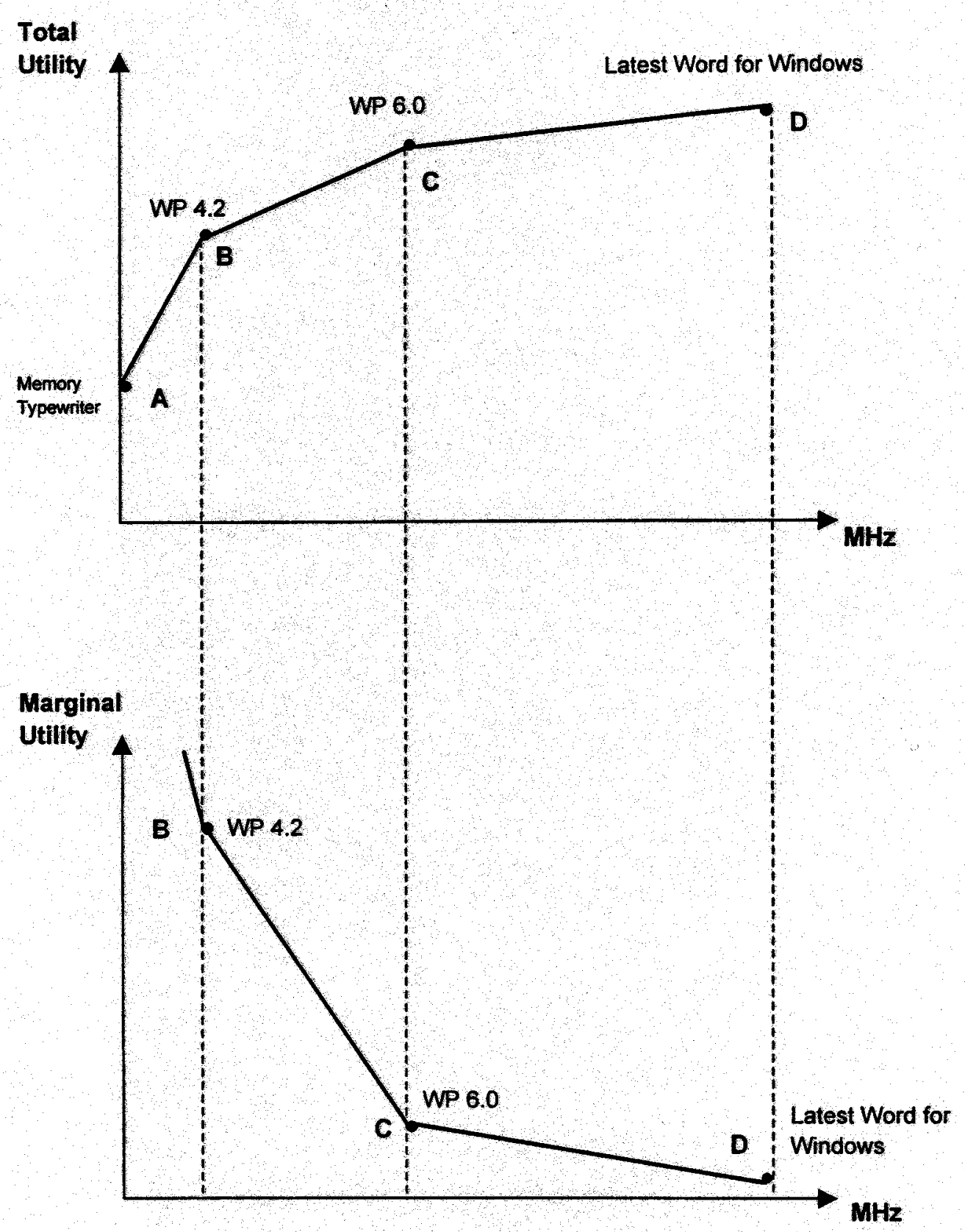


Figure 6

\section{ECONOMISTS WONDER WHY COMPUTERS HAVEN'T BOOSTED PRODUCTIVITY}

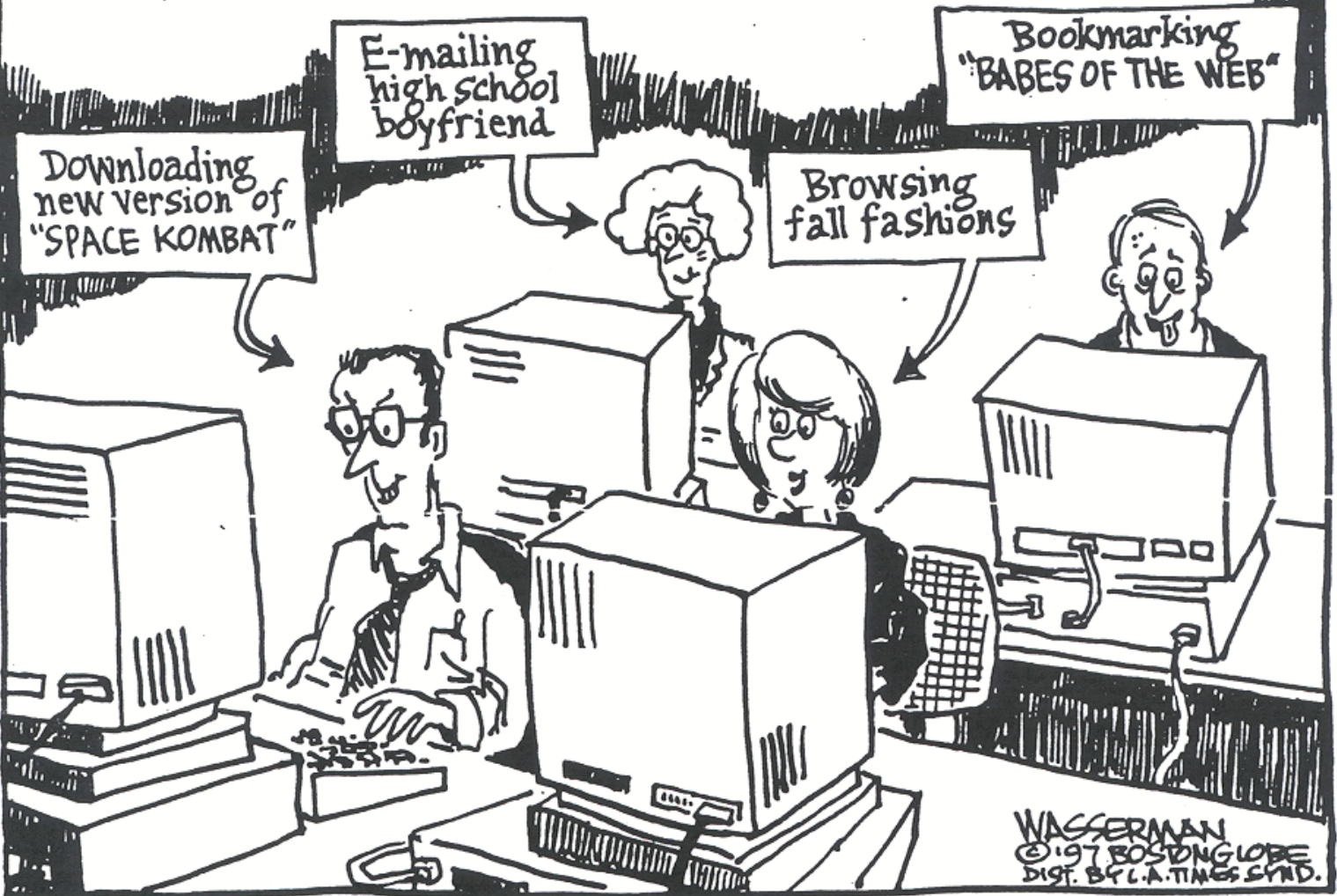




\section{(Supplement) \\ The Greatest Decade: \\ The Honor Roll of Inventions, 1876-86}

\begin{tabular}{|c|c|c|c|}
\hline Invention & Year & Inventor & Comments \\
\hline \multicolumn{4}{|l|}{ Electricity } \\
\hline Electric Light & 1879 & $\begin{array}{l}\text { Thomas Alva } \\
\text { Edison (US) and } \\
\text { Joseph Wilson Swan } \\
\text { (UK) }\end{array}$ & \\
\hline Electric Transformer & 1879 & Elihu Thomson & \\
\hline Electric Railway & 1879 & $\begin{array}{l}\text { Werner von } \\
\text { Siemens }\end{array}$ & $\begin{array}{l}\text { Shown at an exhibition; first } \\
\text { streetcar service (to a Berlin } \\
\text { suburb) in } 1881\end{array}$ \\
\hline Power Station & 1882 & $\begin{array}{l}\text { Thomas Alva } \\
\text { Edison }\end{array}$ & $\begin{array}{l}\text { First in London, second the Pearl } \\
\text { Street station in NYC, both built } \\
\text { by Edison in the same year }\end{array}$ \\
\hline Steam Turbine Generator & 1884 & $\begin{array}{l}\text { Charles Algernon } \\
\text { Parsons }\end{array}$ & \\
\hline \multicolumn{4}{|l|}{$\begin{array}{l}\text { Internal Combustion } \\
\text { Engine and } \\
\text { Transportation }\end{array}$} \\
\hline Internal Combustion Engine & 1877 & Nikolaus Otto & $\begin{array}{l}\text { Four-cycle engine "the basis of the } \\
\text { most common type of engine } \\
\text { today". Previous versions } \\
\text { developed by Lenoir (coal gas, } \\
\text { 1859), Rochas (four-stroke, 1862), } \\
\text { Hock (liquid gasoline, 1870) }\end{array}$ \\
\hline Automobile & 1885 & Karl Benz & $\begin{array}{l}\text { Three-wheeled; also in } 1885 \text { first } \\
\text { motorbike invented by Gottlieb } \\
\text { Daimler (first four-wheeled auto in } \\
1887 \text { by Daimler) }\end{array}$ \\
\hline Dirigible & 1884 & $\begin{array}{l}\text { Charles Renard and } \\
\text { Arthur C. Krebs }\end{array}$ & $\begin{array}{l}\text { Powered by electric motor, first } \\
\text { capable of being steered well } \\
\text { enough to return to launch point }\end{array}$ \\
\hline
\end{tabular}




\begin{tabular}{|c|c|c|c|}
\hline Invention & Year & Inventor & Comments \\
\hline \multicolumn{4}{|l|}{ Chemicals, Materials } \\
\hline Reinforced Concrete & 1877 & Joseph Monier & \\
\hline Ivory soap & 1878 & & $\begin{array}{l}\text { Soap that floats was discovered by } \\
\text { accident. }\end{array}$ \\
\hline \multicolumn{4}{|c|}{$\begin{array}{l}\text { Entertainment, } \\
\text { Communications, Misc. }\end{array}$} \\
\hline Telephone & 1876 & $\begin{array}{l}\text { Alexander Graham } \\
\text { Bell }\end{array}$ & $\begin{array}{l}\text { "Mister Watson, come here, I want } \\
\text { you." }\end{array}$ \\
\hline Motion Picture Camera & 1881 & Etienne-Jules Marey & $\begin{array}{l}\text { First true motion picture by } \\
\text { Edison and William Dickson in } \\
1888\end{array}$ \\
\hline Phonograph & 1877 & Charles Cros & Improved by A. G. Bell in 1884 \\
\hline Vending Machine & 1882 & Percival Everitt & \\
\hline Linotype & 1884 & $\begin{array}{l}\text { Ottmar } \\
\text { Mergenthaler }\end{array}$ & \\
\hline Roll Film & 1884 & $\begin{array}{l}\text { George Eastman } \\
\text { and William } \mathrm{H} . \\
\text { Walker }\end{array}$ & $\begin{array}{l}\text { First commercial roll-film camera } \\
\text { in } 1888\end{array}$ \\
\hline Fountain pen & 1884 & Lewis E. Waterman & \\
\hline Dictaphone & 1885 & Charles S. Tainter & \\
\hline Cash Register & 1879 & James Ritty & $\begin{array}{l}\text { "Ritty's Incorruptible Cashier"; } \\
\text { became commercial success with } \\
\text { National Cash Register Company } \\
\text { (1884) }\end{array}$ \\
\hline \multicolumn{4}{|l|}{ Health, Sanitation } \\
\hline Germ theory of Disease & 1880 & Louis Pasteur & $\begin{array}{l}\text { Publication of "On the extension } \\
\text { of the germ theory to the etiology } \\
\text { of certain common diseases" }\end{array}$ \\
\hline Vaccine & 1881 & Louis Pasteur & $\begin{array}{l}\text { First artificially produced vaccine, } \\
\text { against anthrax }\end{array}$ \\
\hline Indoor flush toilet & 1886 & Thomas Crapper & Last but not least \\
\hline
\end{tabular}

Source: Bryan Bunch and Alexander Hellemans, The Timetables of Technology. New York, Touchstone Press, 1994, pp. 258-95.

Note: $\quad$ Five "clusters" of inventions are listed in the same order as the discussion of Great Inventions on pp. 22-26 above. 